\title{
Study of physical and chemical properties of vitrinites. Inferences on depositional and coalification controls
}

\author{
A. Jiménez ${ }^{\text {a, }}{ }^{*}$, M. J. Iglesias ${ }^{\mathrm{a}}$, F. Laggoun-Défarge $^{\mathrm{b}}$ and I. Suárez-Ruiz ${ }^{\mathrm{a}}$ \\ a Instituto Nacional del Carbón (CSIC), Ap. Co. 73, 33080 Oviedo, Spain \\ ${ }^{\text {b }}$ URA. 724 du CNRS/F.U. 09, Université d'Orléans, BP 6759, 45067-Orléans Cedex 2, \\ France
}

\begin{abstract}
A detailed study of petrological, geochemical, textural and coking properties was carried out on vitrains from the Puertollano, Blanzy-Montçeau, Asturias and Teruel. The objective was to determine in depth the physical and chemical properties of a series of natural and pure vitrinites of different rank, and the influence that the sedimentary and post-sedimentary conditions had on them. It is demonstrated that although vitrains are almost entirely made up of the huminite/vitrinite maceral group they have a different composition, thermal behaviour and physical properties. Thus, geochemical and textural properties of Blanzy-Montçeau vitrains can be considered to be representative of the telinite, the major component in both samples $(75 \%$ vol.) at the beginning of the bituminization stage (subbituminous/high volatile $\mathrm{C}$ bituminous coals). The characteristics of the Puertollano vitrains described here can also be attributed to the telocollinite ( $>80 \%$ vol.) for the high volatile $\mathrm{C}$ bituminous coal. Variations in physico-chemical properties between Puertollano and Blanzy-Montçeau vitrains are due to the differences in the initial composition of organic matter. Slight differences (i.e., bed moisture content or porosity) between vitrains from the two coal seams in the same basin can be attributed to their stratigraphic position. Several parameters such as $S_{2}, H I$, oil and extraction yield and fluorescent properties suggest that the Puertollano and Blanzy-Montçeau vitrains have a lower hydrocarbon potential. The relationships between geochemical and textural properties make it possible to distinguish between 'normal' and perhydrous vitrains. The two different hydrogen-enrichment processes that occur in vitrains from the Teruel and Asturias basins can be distinguished from the extraction yield data.
\end{abstract}

Author Keywords: Vitrinites; Physical properties; Chemical properties

\section{Introduction}

Vitrinite is the major maceral group in humic coals and contributes significantly to their behaviour in industrial processes. Reflectance of vitrinite is a rank parameter widely used for geological studies (geothermal history of basins), classification, exploration and fossil fuels utilisation. Moreover, this parameter can be used to predict coal properties. The importance of this maceral group is clearly reflected by the large numbers of papers published (Brown et al., 1964; Kuehn et al., 1982, Jones et al., 1984; Hatcher, 1989; Hatcher et al., 1992; Dyrkacz et al., 1991; Mastarlerz and Bustin, 1993a; Mastarlerz and Bustin, 1993b and Mastarlerz and Bustin, 1994; Iglesias et al., 1995; Newman et al., 1997; among others). It is well known that the optical (reflectance) and chemical properties of vitrinite change as rank increases. However, variations in vitrinite chemistry may be due to factors other than differences in maturity (e.g., Newman and Newman, 1982). In iso-rank coals, vitrinite with the same textural and optical characteristics might not be homogeneous with respect to its chemical properties (e.g., Jones et al., 1984). It should be emphasised, however, that vitrinite is not a single homogenous material but a maceral group composed of a number of different maceral 
types. The chemical composition and reflectance of the vitrinite macerals may also vary depending on both the nature of the precursors and the biochemical alteration that they have undergone during the early stages of diagenesis (e.g., Mastarlerz and Bustin, 1997). In some cases, geological factors such as origin, depositional environment conditions or postsedimentary processes can modify the chemical and physical properties of vitrinite (e.g., Hutton and Cook, 1980; Teichmüller, 1987; Mastarlerz, 1991; Fang and Jianyu, 1992; Veld et al., 1994; Suárez-Ruiz et al., 1994aSuárez-Ruiz et al., 1994b). From the above considerations, it is clear that vitrinite is a complex subject. This is because variations are not only affected by rank but also by paleoenvironmental conditions and post-sedimentary history. For this reason, a detailed study of vitrinite characteristics with special attention to relationships between physico-chemical properties will contribute to a better understanding of both coal genesis and postsedimentary controls. Further knowledge about this maceral group is also required for a more efficient utilisation of the parameters available from vitrinite in the fields of geology and industry.

Coal is made up of small entities or finely mixed macerals inside a complex matrix. The possibility of obtaining maceral concentrates in laboratory experiments has allowed some progress to be made in the study of vitrinite. Various mechanical techniques based on density gradient separation methods have been used in most works on single macerals. This technique makes it possible to isolate some macerals such as vitrinite, alginite and inertinite, but not all macerals can be separated (Dyrkacz et al., 1984; Crelling et al., 1988; Hatcher et al., 1994, Stankiewicz et al., 1996). Moreover, the concentration of macerals involves chemical demineralisation which can lead to modifications in coal structure. On the other hand, in situ micro analytic techniques (microprobe, micro FTIR) have been used to study the chemistry of individual macerals. Microprobe provides accurate and precise compositional data for both major $(\mathrm{C}, \mathrm{O})$ and minor elements $(\mathrm{S}, \mathrm{Si})$. Data on functional groups of macerals can be obtained by using micro FTIR in transmission or reflectance mode (Rochdi and Landais, 1991; Mastarlerz and Bustin, 1993a; Mastarlerz and Bustin, 1993b and Mastarlerz and Bustin, 1997). Although they represent an important step forward in the characterisation of single macerals, these techniques do have their limitations. They are conducted on restricted areas of the sample so that from the conclusions obtained by means of microscale characterisation it might be difficult to predict the behaviour of the material as a whole during the processes of conversion and utilisation. The use of pure vitrinite isolated from a vitrain lithotype in coalbeds (International Committee of Coal Petrology, 1975) can provide a relatively high amount of sample necessary to study as many vitrinite properties as possible. Consequently, the problem of previous physico-chemical treatment is avoided. However, this requires macroscopic separation of vitrain layers and not all of the coal seams have very bright layers with a thickness of several millimetres $(>3)$, which make it possible obtain high amounts of vitrain sample. In fact, the most common macroscopic constituent of humic coal is clarain, which consists of thin layers of vitrain $(<3 \mathrm{~mm}$ ) and durain (International Committee of Coal Petrology, 1975). The lack of lateral continuity of the vitrain beds and their thinness make identification and sampling more difficult. Of course, vitrains of increasing rank taken from the same basin and covering as wide a range as possible would be the best option for studying evolution via the chemistry of vitrinites. However, this would not be possible in most coal basins.

Two Carboniferous coal basins (Montçeau-Les Mines and Puertollano) from France and Spain and two Mesozoic coal basins (Asturias and Teruel) from Spain were chosen for this study. Previous papers have shown that vitrinites from Asturias and Teruel have undergone different hydrogen-enrichment processes during their geological history (Suárez-Ruiz et al., 
1994aSuárez-Ruiz et al., 1994b; Jiménez, 1995). Moreover, the FTIR study of both perhydrous vitrains (Iglesias et al., 1995) suggest that the processes of hydrogen-enrichment affect the macromolecular structure of the vitrinite, hindering the normal increase in reflectance.

The objective of this work is to determine physical and chemical properties of pure vitrinites using combined optical, chemical, textural and coking analyses. Compositional and rank (petrographic and chemical) parameters give valuable information on the diagenetic history of each vitrain. Comparison between Carboniferous and Mesozoic vitrains clearly shows that the hydrogen-enrichment process confers properties and behavioural characteristics different to those of vitrains with normal content in hydrogen (Puertollano and Blanzy-Montçeau vitrains). The differences between the two natural hydrogen enrichment processes that affect Asturias and Teruel vitrains are discussed in the light of these petrographic, geochemical, textural and coking properties. A comparison of Carboniferous vitrains (Puertollano and Montçeau-Les Mines) of different geological origin reveals the influence of the sedimentary environment conditions. Vitrains taken from two coal seams in the Puertollano and MontçeauLes Mines basins allow small variations to be attributed to their stratigraphic position.

\section{Samples and geology}

A set of six representative samples with the characteristics described for vitrain (International Committee of Coal Petrology, 1975) were selected from four coal basins (Montçeau-Les Mines, Puertollano, Asturias and Teruel) in Spain and France (Fig. 1). In this work, samples are denoted as Bv and Fv (from Blanzy-Montçeau, seams Barrat and Fouthiaux respectively), Pv2 and Pv3 (from Puertollano, seams 2 and 3 respectively), Av (from Asturias) and Tv (from Teruel). These vitrains are of different origin, age and geological history. In all cases, vitrains were collected by handpicking in working areas in order to obtain unweathered samples.

Fouthiaux and Barrat coals from the Montçeau-Les Mines Carboniferous (Stephanian) basin (France) originated in a swamp environment located on alluvial fans close to a major border fault (Vallé, 1984). Vitrains from these seams originated from trunks and branches which were well preserved due to a relatively dry climate and calm conditions (Wu, 1990). The Fouthiaux seam is located at a higher stratigraphic level than the Barrat seam (Fig. 1b). Both vitrains ( $\mathrm{Fv}$ and $\mathrm{Bv}$ ) occur as lenses less than $1 \mathrm{~cm}$ thick.

Coal seams 2 and 3 from the Puertollano Carboniferous (Stephanian) basin (Spain, Fig. 1c) originated in a lacustrine environment (Wallis, 1983). Vitrain layers are very common in these coal seams and are not very thick $(<2 \mathrm{~cm})$, with a relatively high lateral continuity $(<1 \mathrm{~m})$. Slight differences in sedimentary environmental conditions for coal seams 2 and 3 were found by Marques (1987). This author suggested the influence of reducing conditions during the formation of coal seam 2 as a result of deeper water, and a more oxygenated environment for coal seam number 3 due to the oscillation of the thin layer of water covering the peat.

Asturian coal from the Jurassic basin (Spain, Fig. 1a) occurs inside detrital facies dated as Malm (Kimmeridgian) by Suarez Vega (1974) and Campon et al. (1978). This vitrain (Av) originated from wood drifted by streams and was deposited on a delta in a transitional marinecontinental sedimentary environment (Valenzuela et al., 1986). The vitrain layers show variable dimensions (from 1,5 to $8 \mathrm{~m}$ in length and from 2 to $6 \mathrm{~cm}$ in thickness). Asturian coal is found on top of Pliensbachian sediments, which are considered to be a source-rock in this 
part of Northern Spain (Suárez-Ruiz and Prado, 1995). Impregnation by oils from these infraadjacent sediments has been described for this coal (Suárez-Ruiz et al., 1994a).

Coal seams of the Teruel coal basin (Spain, Fig. 1d) of Cretaceous age (Cervera et al., 1976) are located in the Escucha Formation, which originated in a delta-estuary depositional environment (Querol et al., 1991). The vitrain was formed by driftwood carried away by streams and incorporated into the swamp. The vitrain in the coal seams occurs as lenticular bodies with variable thickness $(<15 \mathrm{~cm})$ and significant lateral continuity $(<60 \mathrm{~cm})$. Sample $\mathrm{Tv}$ was taken from seam number 4 from the underground Concepcion mine.

\section{Analytical methods}

A detailed study of vitrains was carried out using petrological, geochemical, textural and coking properties and the samples were prepared according to standard procedures and international normative in each case.

Maceral analyses and reflectance measurements were carried out on a MPVII Leitz microscope using oil immersion objectives $(50 \times)$ and following the procedures described in International Standard Procedures ISO-7404/3 (1984); ISO-7404/5 (1984), respectively. Qualitative fluorescence analyses was performed with a MPVIII Leitz microscope using oil immersion and blue light. The vitrinite ultrastructure was studied on grains crushed to $<1 \mathrm{~mm}$ using a SEM Philips CM-20 instrument.

Proximate analyses and calorific value were made in accordance with International Standard Procedures (ISO-589, 1981; ISO-1171, 1981; ISO-562, 1981; ISO-1928, 1976). The C, H, N and total S were determined using a LECO CHN 600 and LECO SC 132 apparatus and the oxygen content was calculated by difference. The oil and gas yields of the vitrains were obtained by means of Gray-King Assay (ISO-502, 1981). The composition of the gases (up to butane) released from Gray-King pyrolysis was analysed using a Perkin Elmer 900 equipped with a FID detector and a $4 \mathrm{~m} \times 1 / 8$-inch porapack-Q packet column, operated at $70^{\circ} \mathrm{C}$ using $\mathrm{H}_{2}$ as carrier gas. To determine the $\mathrm{CO}$ and $\mathrm{CO}_{2}$ concentrations of these gases, Konick-knk2000 equipment with two columns of $80-100$ mesh active carbon $(4 \mathrm{~m} \times 1,8 \mathrm{in}$.) and a molecular sieve of $5 \AA$ was connected to a thermal conductivity detector (TCD) at $100^{\circ} \mathrm{C}$ and $240 \mathrm{~mA}$. The gas volume injected in both cases was $100 \mu \mathrm{l}$. Other parameters related with the origin, composition, rank, gas and oil yields of the different vitrains were obtained from Rock-Eval $^{\mathrm{TM}}$ pyrolysis performed in accordance with Espitalie et al. (1977). Thermogravimetric pyrolysis was carried out at a heating rate of $10^{\circ} \mathrm{C} \mathrm{min}{ }^{-1}$ from 50 to $1000^{\circ} \mathrm{C}$ under nitrogen $\left(60 \mathrm{ml} \mathrm{min}^{-1}\right)$ using Setaram TAG24 equipment. Each experiment was carried out on $25 \mathrm{mg}$ of sample located inside a platinum crucible, which was placed in a relatively uniform temperature region of the furnace. A soluble organic fraction from each raw vitrain was obtained using chloroform as a solvent in an ultrasound bath at room temperature (Blanco et al., 1992). Approximately $8 \mathrm{~g}$ of sample crushed to $<5 \mathrm{~mm}$, was inserted in an ultrasonic bath (Selecta Ultrasounds) and kept at $25^{\circ} \mathrm{C}$ for $2 \mathrm{~h}$. The solution was then filtered (pore size $0.5 \mu$ ) and the residues washed until the filtrate became clear, and then dried to constant weight. The filtrate was desulphurated with a $\mathrm{Cu} / \mathrm{Zn}$ amalgam and isolated from the solvent in a rotator apparatus at reduced pressure. The extracts thus obtained were dried at room temperature to constant weight in order to obtain the extraction yield. The extracts were then fractionated in saturated and aromatic hydrocarbons and NSO by means of chromatographic separation on a Fluorisil ${ }^{\text {TM }}$ mini-column by successive elutions with $n$ heptane and $n$-heptane+toluene $(2 / 1 \mathrm{v} / \mathrm{v})$. 
Textural characterisation was performed through the measurement of true and apparent densities. These data were used to calculate pore volume and porosity. The true density was determined using a glass pycnometer. Samples (ca. $2 \mathrm{~g}$-particle size between 1 to $3 \mathrm{~mm}$-) were degassed at $100^{\circ} \mathrm{C}$ for $3 \mathrm{~h}$ before the introduction of helium. Apparent density was determined by means of mercury porosimetry using a Carlo Erba Macropore Unit 120 apparatus. The samples were dried and degassed before being filled with mercury. The same equipment was used to measure the accumulative pore volume of a pore size $\left(D_{\mathrm{p}}\right)$ with a diameter greater than $7.50 \mathrm{~nm}$. The distribution of the pore size allowed the separation of macro- $\left(D_{\mathrm{p}}>50 \mathrm{~nm}\right)$ and meso-pores $\left(50 \mathrm{~nm}>D_{\mathrm{p}}>7.50 \mathrm{~nm}\right)$. The approximate micropore volume was calculated by difference.

The coking properties, free swelling and Audibert-Arnu swelling, were obtained according to UNE-32005; ISO-349 (1975) procedures, respectively. Free swelling was performed on all the samples and an Audibert-Arnu swelling assay was carried out only on those samples with a volatile matter content ranging between $15 \%-40 \%$ and an ash content of less than $9 \%$ according to the criteria proposed by van Krevelen (1993).

\section{Results and discussion}

All the vitrains chosen present typical megascopic characteristics for this lithotype as defined by International Committee of Coal Petrology (1975). In general terms, they have a bright black colour, a homogeneous and compact appearance, and a cubic or conchoidal fracture with straight and sharp edges. Moreover, Tv, Fv, Bv, Pv2 and Pv3 show numerous cracks or fractures on their external surface. Av has straight and sharp edges without cracks and was defined as a Jet by Suárez-Ruiz et al., 1994a.

\subsection{Petrology}

\subsubsection{Vitrinite reflectance}

Random reflectance values (Fig. 2) show that the vitrains are placed in a narrow rank series. Sample $\mathrm{Fv}$ is located at the transition between subbituminous/high $\mathrm{C}$ volatile bituminous coal. Samples Pv2, Bv and Pv3 are high C volatile bituminous coals $\left(R_{\mathrm{o}}\right.$ ranging from 0.6 to $\left.0.7 \%\right)$. In the samples from Blanzy-Montçeau, the lower rank obtained for Fv $\left(R_{0}=0.53 \%\right)$ compared to that of $\mathrm{Bv}\left(R_{\mathrm{o}}=0.67 \%\right)$ is in agreement with the higher stratigraphic position of Fv (Fig. 1b). Similarly, the reflectance values of Pv2 are lower than those found for Pv3 due to their stratigraphic position (Fig. 1c).

The vitrinite reflectance of samples $A v$ and $T v$ is suppressed (Suárez-Ruiz et al., 1994aSuárez-Ruiz et al., 1994b) and therefore, vitrinite reflectance can not be considered as a valuable rank parameter here. For Av, the difference between the reflectance values (Fig. 2) obtained for the two vitrinite components (phlobaphinite and ulminite) is too high $(0.33 \%)$. A previous study (Suárez-Ruiz et al., 1994a) showed that hydrocarbon impregnation/absorption produces reflectance suppression in ulminite (the main component) and the initial differences in reflectance between ulminite and phlobaphinite increased in the subsequent coalification. For this reason, phlobaphinite can be identified after the diagenetic/catagenetic transition when usually it occurs only at low ranks. The reflectance of $\operatorname{Tv}\left(R_{0}=0.23 \%\right)$ is also suppressed due to the resinization of its huminite in the stages before its incorporation into the depositional environment (Suárez-Ruiz et al., 1994b). Based on the results obtained by these authors, the Tv vitrain represents the beginning of the bituminization interval (subbituminous 
A-B coal). So, a vitrinite reflectance value of ca. $0.45 \%$ could be considered as the value that determines the real rank reached by Tv and according with that previously published (Querol et al., 1991). Both values, the one measured in $\mathrm{Tv}(0.23 \%)$ and the one deduced $(0.45 \%)$ are shown in Fig. 2.

\subsubsection{Maceral composition}

The vitrains are almost exclusively made up of the huminite/vitrinite maceral group (Fig. 3). Except for Tv with 3\% liptinite (resinite), the minor liptinite and/or inertinite macerals present $(<0.5 \%$ vol.) in the vitrains could be considered as impurities due to the adherence of the whole coal. A more detailed maceral analysis shows that the occurrence of different vitrinite macerals varies considerably from one vitrain to another (Fig. 3). As vitrains from Asturias $(\mathrm{Av})$, Teruel $(\mathrm{Tv})$, Fouthiaux $(\mathrm{Fv})$ and Barrat $(\mathrm{Bv})$ derive from woody trunks and stems, they are made up of structured tissues, ulminite in Tv (Fig. 4a), Av (Fig. 4b) and telinite in Fv and Bv (Fig. 4c). These macerals have cellular walls and cell cavities, which can be filled with huminite (phlobaphinite) in Av, vitrinite (collinite) in Fv and Bv or liptinite (resinite) in Tv.

The petrographic character of vitrains from Puertollano (Pv2 and Pv3) is different to that of the others (Fig. 3). They are made up of a relatively homogeneous material, telocollinite (Fig. $4 d$ ), with tissue remains in some of its particles (not all of them). This feature suggests that telocollinite could have originated from telinite, which has subsequently been homogenised. Bearing in mind the similar rank of $\mathrm{Bv}$ and $\mathrm{Pv} 3$, the different degree of gelification of the plant tissues must be mentioned. Thus, telinite shows well-defined structures in Bv but homogenised features in Pv3. This difference could be related to the environmental conditions of the two coal basins. Thus, in Puertollano, sedimentary conditions must favour the gelification process. Moreover, Pv2 and Pv3 are made up of collinite (Fig. 4d), which has not been identified for the other vitrains studied here. Slight differences in the content of desmocollinite in Pv3 and in Pv2 must be mentioned (Fig. 3). Mukhopadhyay (1994) explains that higher amounts of desmocollinite are related to gelification processes caused by a higher $\mathrm{pH}$ at the sediment-water interface in coal.

\subsubsection{Fluorescence properties}

The development of vitrinite secondary fluorescence might be expected for Bv, Pv2 and Pv3 given the reflectance values (Fig. 2) and the fact that they are inside the bituminization stage. Secondary vitrinite fluorescence has been attributed to liquid bituminous products formed from liptinite and perhydrous vitrinite (Teichmüller and Durand, 1983). Moreover, Lin and Davis (1988) have demonstrated that the compounds responsible for the strong fluorescence are concentrated in the 'mobile fraction' rather than in the 'macromolecular network'. Extracted fluorophores identified by these authors included a diverse assemblage of aromatic and polar compounds, characterised by strong conjugated double bond systems. Consequently, the absence of secondary fluorescence for samples Bv, Pv2 and Pv3 could be due to a low generation of liquid bitumen as a result of their almost pure vitrinitic nature and low amounts of hydrogen-rich macerals (liptinite, desmocollinite, etc.).

Fluorescence properties are only observed in samples Tv and Av and the results have been reported in previous works (Suárez-Ruiz et al., 1994aSuárez-Ruiz et al., 1994b). These authors point out that fluorescence properties observed in Tv and Av, do not correspond to the development of secondary fluorescence in 'normal' vitrinites (as defined by Lin et al., 1986). Suárez-Ruiz et al. (1994a) concluded that some of the characteristics found in Av ulminite 
fluorescence (slight + spectral alteration) in comparison with the secondary fluorescence of vitrinites could be the result of the different source of impregnation in this coal (oils migrated from other sediments). Suárez-Ruiz et al. (1994b) point out that fluorescence parameters for both ulminite and resinite in Tv (identical position of peak of maximum intensity, similar $\lambda \max$, QF-535, Q650/500,) are close to those obtained by different authors for resinite (Fig. 6 in Suárez-Ruiz et al., 1994b). These authors concluded that the resinous compounds of the tissue induced ulminite fluorescence, which is a primary fluorescence. The resinization process occurred before the incorporation of the plant precursor into the peat. The detection of exudates generated from resinous substances contained in the vitrain suggests that $\mathrm{TV}$ is at the beginning of the bituminization interval.

A comparison of the fluorescence parameters of the perhydrous vitrains (Av and Tv) allows the different origin of the hydrogen-enrichment process (impregnation by oils and resinization, respectively) to be determined.

\subsubsection{Ultra-structure study}

The SEM examination for Tv reveals the presence of woody structures with aligned cellular walls and cavities (Fig. 5a) that might correspond to the cellular structures observed by means of optical microscopy (Fig. 4a). Cell walls show a porous texture while cavities are filled with

a denser smooth matrix. As might be expected from the rank reached by this vitrain (beginning of bituminization stage), no gelification features have been found. Sample Av is simply composed of an amorphous matrix (Fig. 5b) with a conchoidal fracture. An examination of $\mathrm{Fv}$ and $\mathrm{Bv}$ reveals several structures that indicate the presence of plant cell walls, which show the form of a sinuous, and continuous layer (Fig. 5c). The latter delimits the cellular cavities, which in some cases are filled with an amorphous matrix. Sample Bv shows a slightly stronger gelification and homogenisation than Fv in agreement with the reflectance values reported for both vitrains. The ultrafine structure of Pv2 and Pv3 is very similar to that found in Av but shows conchoidal fracture, a more compact amorphous matrix and a porosity of ca. $100 \AA$ (Fig. 5d). The gelification degree in Pv2 and Pv3 vitrains is more marked than in $\mathrm{Fv}$ and $\mathrm{Bv}$ in agreement with optical microscopy observations that showed tissue remains in some telocollinite particles of Puertollano vitrains. On the other hand, X-ray diffraction data discussed by Laggoun-Defarge et al. (1994) reveal the poor structural organisation of the vitrains studied here as might be expected from their rank (Fig. 2). Moreover, Tv and Av vitrains show weak (002) reflection (3.65 $\AA$ ) when compared with the other vitrains studied here (3.82 $\AA$ ).

\subsection{Chemical properties}

The results from proximate and ultimate analyses as well as the calorific value are given in Table 1. A general trend of chemical properties as a result of an increase in rank cannot be expected because of the narrow rank of the vitrains studied (Fig. 2). These vitrains have an almost pure organic composition with low ash content (Table 1). The high volatile matter content of Av and Tv must be emphasised (Table 1). Moisture values are relatively high for $\mathrm{Tv}, \mathrm{Fv}, \mathrm{Bv}, \mathrm{Pv} 2$ and Pv3 and exceptionally low for Av when compared with other vitrinite data reported by Stach et al. (1982) and van Krevelen (1993). The wide difference between the moisture values obtained for the two vitrains from Puertollano (Pv2 and Pv3) deserves special mention because of their similar rank and petrographic characteristics. The lower moisture value in Pv3 agrees with the higher physical compaction of seam 3 as a result of its lower stratigraphic position (Fig. 1c). Similarly, the slight differences found between Fv and 
$\mathrm{Bv}$ can also be attributed to their stratigraphic position (Fig. 1b). Table 1 shows a lower nitrogen and sulphur content for all the vitrains.

The $\mathrm{H} / \mathrm{C}$ and $\mathrm{O} / \mathrm{C}$ atomic ratios of the vitrains are depicted in the van Krevelen diagram (Fig. 6). Except for Av and Tv, which are perhydrous vitrinites, the samples fall inside the band of humic coals (type III). The position of Av and Tv is similar to that established for perhydrous coals from New Zealand (Newman et al., 1997). As samples studied here constitute a narrow rank series, only a slight decrease in the atomic ratios is observed from Fv to Pv3, this decrease being more marked in the $\mathrm{O} / \mathrm{C}$ atomic ratio. These results agree with the increase in rank from $\mathrm{Fv}$ (subbituminous/high volatile $\mathrm{C}$ bituminous coal) to Pv3 (high volatile $\mathrm{C}$ bituminous coal).

The relationship between vitrinite reflectance and chemical properties (hydrogen, carbon and volatile matter contents) for the vitrains (Table 1) are shown in Fig. 7. The comparison of these data sets with the correlation bands established by Teichmüller (1971) for humic coals is also presented.

The hydrogen content is very similar for samples Fv, Bv, Pv2 and Pv3, which are located inside the band established for humic coals (Fig. 7). Samples Tv and Av show abnormally high hydrogen values when compared with the other vitrinites and with data reported by van Krevelen (1993). Previous works (Suárez-Ruiz et al., 1994aSuárez-Ruiz et al., 1994b) show that both samples, Tv and Av, have been affected by hydrogen-enrichment processes during their plant life and diagenetic stages. These pre- and post-sedimentary events could have an influence on the correlation between petrographic and chemical rank parameters in agreement with Jones et al. (1984).

Samples Fv, Bv, Pv2 and Pv3 are located inside the correlation band for carbon content and reflectance values. The carbon content does not correlate with reflectance values measured for Av (ulminite reflectance) and Tv. The carbon content for Av is more concordant with phlobaphinite (the minor component) reflectance. For Tv, the carbon content is too high for the reflectance measured $(R=0.23 \%)$ but not too high for the reflectance deduced $(R=0.45 \%)$. The disagreement between the carbon content and reflectance values reinforces the idea that reflectance depends on the quantitative structural changes of the coal molecule and not on the total carbon content as reported by Petrova et al. (1985).

Concerning the correlation between volatile matter and vitrinite reflectance (Fig. 7), the position of $\mathrm{Fv}, \mathrm{Bv}, \mathrm{Pv} 2$ and $\mathrm{Pv} 3$ suggests a slightly lower volatile matter than that established for coals with similar reflectance values. This feature could be attributed to the almost pure vitrinite composition in the vitrains, without liptinite macerals that are normally present in coals. The correlation between volatile matter and vitrinite reflectance may not be satisfactory because of the volatile matter content of the vitrains studied here (V.M.>31\%, Table 1) in agreement with Jones et al. (1984). The other vitrains, Tv and Av (ulminite reflectance) are located inside the correlation band established by Teichmüller (1971). However, the volatile matter content of $A v$ is too high for phlobaphinite reflectance $\{\operatorname{Av}(f)\}$.

The correlations between petrographic and chemical properties shown in Fig. 7 make it possible to determine differences in properties. These differences are due to the hydrogenenrichment processes undergone by Av and Tv. For the other vitrains, significant differences in maceral composition between Puertollano and Blanzy-Montçeau vitrains (Fig. 3) are not reflected in chemical properties (hydrogen, carbon and volatile matter content). 
The calorific values obtained are very similar for all the samples except Av (Table 1). Sample Av shows the highest value, which may also be considered high when compared with data reported by van Krevelen (1993) for vitrinites with a carbon content of $\approx 85 \%$. Newman et al. (1997) have reported similar values of calorific value than Av for other perhydrous coals (\% $\mathrm{H}=6.3$ ) with a carbon content of $\approx 85 \%$. The volatile matter content reported by Newman et al. (1997) for the perhydrous coals is considerably lower than that reported for Tv and Av (Table 1). This disagreement between the calorific value and volatile matter content of the perhydrous vitrains cannot be overemphasized. The high hydrogen content of Tv does seem not to affect the calorific value (Table 1). Differences between calorific values and hydrogen content for $\mathrm{Av}$ and $\mathrm{Tv}$ might reflect the influence of different hydrogen-enrichment processes and subsequent hydrogen evolution mechanism for the two vitrains.

\subsection{Thermal behaviour}

\subsubsection{Thermogravimetry}

Fig. 8a shows the TG curves and Fig. 8b the DTG curves obtained for the six vitrains studied. As can be observed in Fig. 8a, the thermogravimetric curves of Av and Tv show a similar tendency to type I kerogens described by Durand-Souron (1980). The other vitrains undergo a smaller weight loss, showing the typical behaviour of terrestrial type III kerogens (DurandSouron, 1980). In all cases, the DTG curves show two maxima (Fig. 8b). The first one results from the evolution of residual adsorbed or chemisorbed water and occluded gases. The second and more prominent one $\left(\mathrm{DTG}_{\max }\right)$ corresponds to tar departure. The two perhydrous vitrains (Av and Tv) start to decompose at a lower temperature than the others (Fv, Bv, Pv2 and Pv3) indicating the presence of thermally more labile groups. Furthermore, Av and Tv are characterised by the presence of a narrower and more symmetrical maximum in the main rate of decomposition $\left(\mathrm{DTG}_{\max }\right.$ ) and a higher rate of the main decomposition than the other vitrains. Smutkina et al. (1982) points out that the different symmetries of the $\mathrm{DTG}_{\max }$ could be related to the different contributions of the destructive and polycondensation processes during the thermal decomposition of coals. In agreement with these authors, the more symmetrical $\mathrm{DTG}_{\max }$ obtained for Av and Tv suggests that the destructive process is more likely to occur, whereas, in the other vitrains polycondensation reactions prevail.

It is well known that the maximum rate of weight loss decreases as the rank $(\% \mathrm{C})$ increases (van Krevelen, 1993). The high rate of loss in weight found in Av and Tv clearly does not agree with their carbon content (Table 1). Neither of the relationships between these parameters can be observed in other vitrains (Fig. 8b) probably due to the narrow range of carbon content. Nevertheless, it is worth noting that the vitrains from Blanzy-Montçeau (Fv and $\mathrm{Bv}$ ) show a higher rate of weight loss than those from Puertollano (Pv2 and Pv3). Although differences in petrographic composition are not reflected in the chemical analysis (Table 1) they do affect the thermal behaviour of these vitrinites, suggesting structural differences between vitrains from Puertollano (Pv2 and Pv3) and Blanzy-Montçeau (Fv and $\mathrm{Bv})$.

$\mathrm{DTG}_{\max }$ values (Table 2) are close to those reported by van Krevelen (1993) for vitrinites with similar volatile matter content, except for Av. This sample (Av) shows a temperature of the maximum rate of weight loss close to that found for Fv and Pv2 in spite of the differences in the volatile matter content of these vitrains (Table 1). On the other hand, the maximum rate of weight loss shifts to higher temperatures as the vitrinite reflectance increases, with the exception of Av. According to the results obtained for the vitrains studied in this work, the 
$\mathrm{DTG}_{\max }$ for Av might be considered too high (too low) when considering the ulminite (phlobaphinite) reflectance values. The results obtained for Av should be attributed to the presence of oils that impregnate the ulminite of this coal.

The combination of the thermogravimetric and chemical analyses allows the carbon aromaticity to be calculated in an indirect way. The values $(A)$ are given in Table 2 and they were determined according to the following equation (Smutkina et al., 1982):

$$
A=[(100-\mathrm{WL}) \times 1200] / 1240 C
$$

WL is the total weight loss at $1000^{\circ} \mathrm{C}$ (Table 2) and $C$ is the carbon content determined by means of chemical analyses (Table 1).

As can be observed in Table 2, the perhydrous vitrains show lower aromaticiy $(A)$ than the other samples. The plot of aromaticity vs. vitrinite reflectance (Fig. 9) exhibits a good linear correlation between these two parameters. This result and the presence of the aromatic band at $1500 \mathrm{~cm}^{-1}$ of the Av and Tv vitrain (Iglesias et al., 1995) suggest that the process of resinization and impregnation have modified the vitrinite network in a different way to that usually described during coalification (Schenk et al., 1990). Thus, the formation of polycyclic units through aromatisation and condensation reactions, the factor chiefly responsible for the increase in vitrinite reflectance (Carr and Willianson, 1990) is hindered, and as a result vitrinite reflectance is suppressed.

\subsubsection{Rock-Eval parameters}

The most significant parameters derived from Rock-Eval pyrolysis $\left(S_{1}, S_{2}, T_{\max }\right.$ and HI) are shown in Fig. 10. In agreement with the small amount of free hydrocarbons present in most coals (Teichmüller and Durand, 1983) the vitrains show very low $S_{1}$ values (Fig. 10a). For the Carboniferous vitrains, the higher $S_{1}$ value in Fv compared to the other samples (Bv, Pv2 and Pv3) agrees with the increase in rank from diagenesis/catagenesis to catagenesis (bituminization stage). On the other hand, the $S_{1}$ values obtained for Av and Tv could be considered very high given the $T_{\max }$ value which is lower than $430^{\circ} \mathrm{C}$ (Verheyen et al., 1984). This can again be attributed to the special composition of these vitrains. In particular, the very high $S_{1}$ values of Av suggest that the $S_{1}$ peak in this vitrain is probably due to the hydrocarbons that impregnate ulminite.

The fact that Av and Tv vitrains have a higher proportion of aliphatic over aromatic structures (Iglesias et al., 1995) is responsible for the very high values of hydrocarbon potential (Fig. $10 \mathrm{~b})$. The other vitrains show a lower hydrocarbon potential $\left(S_{2}\right.$ values $)$ in agreement with the rank and the vitrinitic nature of these samples. Furthermore, the preservation of the organic matter after deposition can affect the hydrocarbon potential (Bertrand, 1989, Curry et al., 1995, between others). The difference in $S_{2}$ (Pv2=65 and Pv3=43) observed in the two Puertollano beds may be due to the fact that the organic matter in seams 2 and 3 is not preserved in the same conditions as a consequence of the more reducing depositional environment (Marques, 1987).

According to the $T_{\max }$ values (Espitalie and Bordenave, 1993), Av and Tv are located in an immature stage, $\mathrm{Fv}$ being located at the beginning of the oil window and $\mathrm{Bv}, \mathrm{Pv} 2$ and $\mathrm{Pv} 3$ 
inside the oil window (Fig. 10c). This agrees with the vitrinite reflectance (ulminite reflectance in the case of Av) of the vitrains and suggests that $T_{\max }$ is affected by the special composition in the same way as vitrinite reflectance. Consequently, $T_{\max }$ is invalidated for perhydrous vitrains as a rank parameter. The hydrogen index values (Fig. 10d) of Av and Tv are higher than those usually found in coals, where this parameter does not exceed $300 \mathrm{mg}$ HC/g TOC (Espitalie et al., 1985 and Espitalie et al., 1986). The position of these two vitrains in the $\mathrm{HI} / T_{\max }$ diagram (Fig. 11) is close to the type II kerogen in agreement with the position in the van Krevelen diagram (Fig. 6). The other vitrains are placed inside the band corresponding to humic coals (type III Kerogen) and their position agrees with the rank determined by petrographic ( $\left.\% R_{\mathrm{o}}\right)$ and chemical ( $\% \mathrm{C}, \% \mathrm{H}$ and $\% \mathrm{~V} . \mathrm{M}$.) parameters.

\subsubsection{Gray-King pyrolysis}

A comparison between the oil and gas yields released during Gray-King pyrolysis at $550^{\circ} \mathrm{C}$ is depicted in Fig. 12. The high oil yield obtained for the vitrains from Asturias and Teruel is consistent with the $S_{2}$ values (Fig. 10b), these samples being oil prone materials. For Fv, Bv, Pv2 and Pv3, a low oil yield was obtained in agreement with their vitrinitic composition (kerogen type III). Considering that Pv2 and Pv3 have a very similar composition and rank, the differences in oil and gas yield are significant.

The composition of the gases released from the Gray-King Assay $\left(550^{\circ} \mathrm{C}\right)$ was studied by means of gas chromatography and the concentration of the major compounds $\left(\mathrm{CH}_{4}, \mathrm{CO}, \mathrm{CO}_{2}\right.$, $\left.\mathrm{C}_{2} \mathrm{H}_{6}, \mathrm{C}_{3} \mathrm{H}_{8}\right)$ is shown in Fig. 13. Methane is the main compound generated from the cracking of kerogen and the oils generated during the pyrolysis process (Tissot and Welte, 1984). The higher methane values obtained for Av might be due to the presence of polar compounds inside the ulminite of the vitrain (Suárez-Ruiz et al., 1994a) which might crack in lighter hydrocarbons such as methane during thermal treatment. The formation of methane and carbon monoxide from vitrinitic structures at temperatures of $550^{\circ} \mathrm{C}$ has been attributed by Hodek et al. (1991) to the cleavage of methylene and biarylether bridges. As can be observed in Fig. 13, the highest amounts of carbon monoxide were obtained for Fv and Bv possibly because of the different origin of Pv2 and Pv3 as mentioned above (maceral composition) and the special chemical composition of $\mathrm{Tv}$ and $\mathrm{Av}$ (perhydrous character). The higher amounts of $\mathrm{CO}_{2}$ in Pv2 with respect to in Pv3 must be mentioned because of their similar rank and composition. This finding might suggest that the different chemical structures of these two vitrains is a result of the different conditions during deposition. Finally, differences between ethane $\left(\mathrm{C}_{2} \mathrm{H}_{6}\right)$ and propane $\left(\mathrm{C}_{3} \mathrm{H}_{8}\right)$ yields show that the lateral chains of the aromatic structure of the vitrains studied here are dissimilar.

\subsection{Extraction yield and composition}

The extract yields and composition are given in Table 2 and Fig. 14, respectively. Sample Tv has a much higher extract yield than the other vitrains, which show very low values in comparison with data reported by other authors (Durand et al., 1977; Lin et al., 1986). The very low amount of chloroform-extractable material of $\mathrm{Bv}, \mathrm{Pv} 2$ and Pv3 together with the absence of secondary vitrinite fluorescence (see fluorescence properties) suggests that the mobile-phase development in these coals is very poor. Fig. 14 shows that the extracts from Av and Tv are similar in composition with very high amounts of polar compounds and a very low proportion of saturated and aromatic hydrocarbons. For the other vitrains, Fv contains a 
higher proportion of saturated and aromatic hydrocarbons and a lower proportion of polar compounds than Bv, Pv2 and Pv3.

Given the characteristics of the solvent employed (chloroform), the relatively high extraction yield of Tv should be attributed to the presence of resinite as well as exudatinite (detected by fluorescence microscopy) in this vitrain. The contribution of an incipient generation of hydrocarbons in the form of exudates is confirmed by the composition of the extract. This is because the most likely composition of exudatinite is asphalteneous (Teichmüller, 1989). Furthermore, the results of fluorescence parameters $\left(\lambda_{\max }\right.$ and $\left.Q 650 / 500\right)$ for both huminite and resinite in this vitrain (Tv) are close to specific types of resinites defined as filled cavities and in some cases as mobilised components (Suárez-Ruiz et al., 1994b). Both the resinite in the cell cavities and the resinite in the huminite tissue in this sample might also act as an extractable mobile phase. Fowler et al. (1991) suggest that mobile-phase resinous material dispersed in the huminite is the responsible for the fluorescence properties and perhydrous nature of a Greek lignite. These authors have found that this material is not strongly bound inside the huminite because it can be extracted. They also suggest that it is responsible for the suppression of vitrinite reflectance, which increases after extraction. In the case of Tv, the extraction yield is much lower than that found by Fowler et al. (1991) and no change in vitrinite reflectance or petroleum potential after extraction was observed. These results suggest that the extractable material in $\mathrm{Tv}$ derives mainly from exudatinite with a certain amount possibly deriving from the resinite that fills the cavities and not from the resine-like substances present in the huminitic structure. These new results again confirm the conclusions obtained in previous works (Suárez-Ruiz et al., 1994b). Thus, the perhydrous character of huminite in $\mathrm{Tv}$ is due to the resinization process of its precursor plant tissues before their incorporation into the depositional environment rather than to an incorporation of lipoidal substances from the huminite precursors. Moreover, taking into account the petrographic composition of the huminite in $\mathrm{Tv}$, these results clearly show that the process of resinisation could modify the lignin framework, hindering the structural reorganisation associated with the increase in reflectance (Schenk et al., 1990).

Vitrain residues obtained after chloroform treatment were petrologically and geochemically characterised. As might be expected from the low extract yield (Table 2), the elimination of material soluble in chloroform does not significantly affect elemental composition, vitrinite reflectance and $T_{\max }$ from Rock-Eval. However, a significant decrease in $S_{2}$ after extraction was detected for Av (from $355 \mathrm{mg} \mathrm{HC} / \mathrm{g}$ rock in the whole sample to $293 \mathrm{mg} \mathrm{HC} / \mathrm{g}$ rock in the extraction residue).

Bearing in mind that kerogen shows a preference for the absorption of polar compounds (Sandvik et al., 1991) the retention of the heavy fraction of hydrocarbons in the ulminite of Av explains the high proportion of polar compounds in this vitrain (Fig. 14). The nature of these compounds must be different to those present in the other samples as is suggested by the decrease in the $S_{2}$ peak after extraction. In general, the decrease in this parameter is attributed to the contribution of heavy bitumen. However, this explanation is not applicable in the case of Av due to the low extraction yield obtained (see Table 2). A reasonable alternative explanation is that the decrease in $S_{2}$ is due to the nature of the soluble material that affects the process of hydrogen donation and/or hydrogen shuttling within the pyrolysis mass. The important role that hydrocarbon plays as a solvating fluid that promotes hydrogen transfer reaction and its influence on the conversion of organic matter has already been demonstrated (Mansuy et al., 1995). Furthermore, the amount of hydrogen exchange necessary for the penetration of tar is small so that the extraction yield does not affect other bulk parameters but 
can bring about a reduction in the amount of generated products during pyrolysis. On the other hand, a higher extraction yield for Av might have been expected in view of the $S_{1}$ value, which is the highest in the vitrains studied (Table 2). One possible explanation for the low extraction yield of Av is that these compounds are not accessible to the solvent because they are retained inside the micropores of the ulminite although heating can expel them. However, the nature of the soluble compounds as other possible cause cannot be ignored. The adsorption forces between the hydrocarbons and the ulminite could be so strong that the chloroform cannot overcome them. On the other hand, the data referring to the extract (yield and composition) indicate clearly the different nature of the hydrogenation processes, which affect perhydrous vitrains ( $\mathrm{Tv}$ and Av).

\subsection{Textural properties}

The results obtained on textural characterisation (true and apparent density, pore volume and porosimetry) are given in Table 3 and Fig. 15. It is well known that true density (mass per volume of organic structure of the coal excluding pores) in vitrinite decreases progressively down to ca. 88\% $\mathrm{C}$ then increases once again at high rank (van Krevelen, 1993). In general, the true density of the vitrains can be considered to be in agreement with their carbon content and the lowest value corresponds to the Av sample with a carbon content of ca. $85 \%$. However, the difference in density values for Tv and Fv, which show similar carbon content values cannot be ignored. It should be pointed out that the helium density is not only dependent on the carbon content but also on the hydrogen content (Fujii and Tsuboi, 1967). van Krevelen (1993) attributed the decrease in density at low rank to the progressive loss of oxygen from the coal structure, at which point hydrogen starts to disappear and density increases. This behaviour, has been quantified by Mazumdar (1988) by means of the following empirical equation:

$$
\rho=2.25-1.192(\mathrm{H} / \mathrm{C})^{1 / 2}+1.06(\mathrm{O} / \mathrm{C})
$$

where $\rho$ (ash free) is true density and $\mathrm{H} / \mathrm{C}$ and $\mathrm{O} / \mathrm{C}$ are atomic ratios.

Taking into account the carbon content of the vitrains, Eq. 2 was used to estimate density. The calculated and experimental values are given in Table 3 . The calculated values for the density are in reasonable agreement with experimental values. The highest deviation was found for Tv, Pv2 and Pv3 probably because the experimental data are not expressed on an ash free basis. In fact, these samples present the highest ash content at around 3\% (Table 1).

The very low porosity and pore volume (Table 3) obtained for the Av sample could be due to the absorption of certain substances into the porosity of this coal as a result of impregnation by petroleum-like substances (Suárez-Ruiz et al., 1994a). In the case of the Tv sample, the values of these parameters, which are similar to those of other vitrinites studied here (Table 3) rule out oil impregnation as a possible explanation for its special characteristics. However, the porosity and pore volume values found in the Tv sample are lower than those found for the 'normal' vitrains except Pv3. The detection (by means of fluorescence microscopy) of exudatinite, which has accumulated inside the pores of the huminite could explain the values of Tv. On the other hand, a decrease in pore volume and porosity with increasing rank can be observed for $\mathrm{Fv}, \mathrm{Pv} 2, \mathrm{Bv}$ and $\mathrm{Pv} 3$ possibly because of plugging by hydrocarbons generated 
during catagenesis. Furthermore, the unequal compaction of the coal seams as a result of their stratigraphic position in the coal basin (Blanzy-Montçeau and Puertollano) must play an important role in the decrease in these properties. The lower values of pore volume and porosity in $\mathrm{Bv}$ compared to $\mathrm{Fv}$ could be related to the expulsion of water as shown by the decrease in moisture content in these vitrains (Table 1). This decrease is caused by the greater compaction of the coal seam in Bv due to its lower stratigraphic level (Fig. 1b). Similarly, Pv2 shows higher porosity and pore volume values as well as higher moisture content (Table 1) than Pv3 because the latter vitrain comes from a coal seam that has undergone higher compaction as the result of its lower stratigraphic position (Fig. 1c). Differences in porosity values for the Puertollano vitrains could have an influence on the oil and gas yield obtained from Gray-King pyrolysis (see Fig. 12).

Fig. 15 shows the distribution of pore size. As can be observed, the amount of macropores present in Av is very close to that found in the other samples. Therefore, the low pore volume and porosity in this sample is due to the low amount of meso- and micro-pores. From these results, it is clear that liquid substances responsible for impregnation occupy these sites. For the other samples, the difference is to be found in the amount of micropores whereas the number of macro- and mesopores are similar for all them. Microporosity has been related to rank (Gan et al., 1972). Thus, it decreases with increasing rank to a minimum at $85 \%$ of carbon content and then increases up to the anthracite coal rank. The decrease in micropore volume for the 'normal' vitrains ( Fv, Pv2, Bv and Pv3) agrees with their rank and this decrease should be attributed to the retention of the small quantities of hydrocarbons generated during the beginning of catagenesis in the porosity of the vitrinite network. On the other hand, the relatively low value of micropore volume for Tv agrees with the accumulation of exudatinite in the micropores of huminite as has been pointed out by Suárez-Ruiz et al. (1994b) and confirmed in this work by the extract yield.

\subsection{Plastic properties}

Table 4 shows the results of the coking properties studied here. None of the samples show plastic behaviour. Nevertheless this is not in agreement with the petrographic characteristics (Huminite/Vitrinite dominant) and chemical properties (volatile matter and ash content) obtained for these vitrains (Table 1). The Av vitrain is the only sample that presents a high Free Swelling value. Impregnation by petroleum-like substances might be responsible for this false swelling behaviour. The abnormal Free Swelling value could serve as an additional proof of the origin of the perhydrous character of this sample. In general, the lower plastic properties (index swelling and Audibert-Arnu swelling) in coals are due to crosslinking reactions (Wolfs et al., 1960), which are facilitated by high oxygen and moisture content. Neavel et al. (1986) have concluded that the plastic behaviour of coals is related to the oxygen and limited by the concentration of inertinite and mineral matter. On the other hand, Lloyd et al. (1990) have demonstrated that the plastic behaviour of coal is connected with the development of a mobile phase. In the vitrains studied in this work, the lack of plasticity might be explained by the relatively high moisture content (Table 1), the high oxygen content (high $\mathrm{O} / \mathrm{C}$ atomic ratio in Fig. 6) and possibly by the lower quantities of mobile fraction deduced from the lack of secondary fluorescence. 


\section{Interpretation and conclusions}

In this work a detailed characterisation of vitrains has been carried out to evaluate the variations in physico-chemical properties in vitrains from Carboniferous and Mesozoic coals. Almost pure vitrinites that show similar maceral group composition have been studied. However, the results of the detailed maceral analysis, microscopic observations and geochemical characterisation, textural and plastic properties indicate significant differences between the vitrains studied. The results also confirm that at low ranks, the Huminite/Vitrinite maceral group is a heterogeneous material composed of a number of macerals, which could be responsible for the different physico-chemical properties. Significant trends in the petrographic and geochemical properties due to increasing rank have not been obtained because of the narrow rank of the vitrains. In general, variations in physico-chemical properties between 'normal' vitrains might be due to the differences in the original composition of the organic matter in the peat. Thus, the different sedimentary environmental conditions between Puertollano and Blanzy-Montçeau vitrains (Fig. 1) could be responsible for the different petrographic features (Fig. 3) and thermal behaviour (Fig. 8, Table 2). Moreover, slight differences (i.e., bed moisture content or porosity) between vitrains from two coal seams in the same basin can be attributed to their relative stratigraphic position. Several parameters such as $S_{2}, \mathrm{HI}$, oil and extraction yield, fluorescent properties suggest that these vitrains show a lower hydrocarbon potential. The relationships between geochemical and textural properties clearly allow 'normal' and perhydrous vitrains to be differentiated. The extraction yield makes it possible to distinguish the nature of the hydrogen-enrichment process for perhydrous coals ( $\mathrm{Tv}$ and Av). Given the above considerations, the interpretation of the results obtained for each vitrain will be made separately.

\subsection{Carboniferous vitrains}

\subsubsection{Blanzy-Montçeau vitrains (Fv and Bv)}

Both vitrains from the Blanzy-Montçeau Basin (France) are similar to one another in maceral composition, microscopic texture, geochemical characteristics and textural properties. These vitrains are made up of almost pure organic material (ash content $<1.5 \%$ ). The physicochemical properties described above could be considered as representative of telinite, the main component in both vitrains $(75 \% \mathrm{vol})$. The minor differences (chemical and textural properties) between them are due to the slightly different rank resulting from their relative stratigraphic positions (Fig. 1b). Optical and SEM observations show that structures found in $\mathrm{Fv}$ are less gelified than those in Bv. The petrographic and chemical rank parameters prove that $\mathrm{Fv}$ is in the subbituminous/bituminous coal transit, whereas the $\mathrm{Bv}$ sample is at the bituminous coal stage. Reflectance values (Fig. 2) and Rock-Eval data (Fig. 10 and Fig. 11) also locate $\mathrm{Fv}$ at the diagenesis/catagenesis limit and $\mathrm{Bv}$ inside catagenesis at the beginning of the oil window. Moreover, the composition extracts (Fig. 14) and FTIR data (Iglesias et al., 1995) suggest differences between the two vitrains that can be attributed to their rank and stratigraphic position (Fig. 1b).

\subsubsection{Puertollano vitrains (Pv2 and Pv3)}

These vitrains are almost entirely composed of vitrinite, although the distribution of their components differs slightly (Fig. 3). The maceral distribution is related to the slightly different nature of the organic matter for coal seams 2 and 3 (Marques, 1987) such as variations in the sedimentary conditions and probably physico-chemical environmental 
events. The presence of desmocollinite and remains of cell structures observed in some of the telocollinite particles suggest that, in coal from seams 2 and 3, gelification process affected the original peat. Moreover, the higher concentration of desmocollinite in Pv3 compared to $\mathrm{Pv} 2$ could be related to gelification due to a higher $\mathrm{pH}$ at the sediment-water interface.

In general terms, telocollinite, the most abundant maceral (95\% vol. in Pv2 and $82 \%$ vol. in Pv3), is responsible for chemical composition (Fig. 6, Fig. 7 and Fig. 8), textural (Table 3) and FTIR data (Iglesias et al., 1995). From the different rank parameters such as carbon and volatile matter content, reflectance and $T_{\max }$ values it can be seen that Pv2 has a slightly lower rank than Pv3. This is due to the higher stratigraphic position of seam 2 (Fig. 1c). All the data obtained indicate that both samples are bituminous coal just inside the 'oil window'. Despite their similar composition and rank, Rock-Eval (Fig. 10 and Fig. 11), Gray-king (Fig. 12 and Fig. 13) and textural data (Table 3 and Fig. 15) suggest that the two vitrains contain distinct organic molecular structures due to the different depositional conditions of the two beds from Puertollano mentioned above (Marques, 1987). Furthermore, differences between Pv2 and Pv3 concerning the oil and gas yield (Gray King pyrolysis) could be related to the different oxidation/reduction conditions of the depositional environment, which may have a significant influence on hydrocarbon generation potential (Curry et al., 1995). Thermogravimetric results also show the influence of maceral composition on thermal behaviour. This finding is very significant because pyrolysis is the basic process for most industrial applications of coal.

Finally, slight differences in composition parameters are observed when Puertollano vitrains are compared with the other carboniferous vitrains (Blanzy-Montçeau). Thus, the maceral composition presented by Pv2 and Pv3 is more heterogeneous than that found for $\mathrm{Bv}$ and $\mathrm{Fv}$. This could be due to the sedimentary origin of Puertollano vitrains (lacustrine environment) which is different to that of Blanzy-Montçeau vitrains (swamp deposits). Nevertheless, these results seem do not affect the chemical composition (Fig. 6, Fig. 7 and Fig. 8), textural (Table 3) or FTIR data (Iglesias et al., 1995).

\subsection{Mesozoic vitrains}

\subsubsection{Teruel and Asturias vitrains (Tv and Av)}

Tv and Av have special properties that distinguish them from the other vitrains studied here. The perhydrous character of $\mathrm{Tv}$ is due to the process of resinization of its plant tissue precursor prior to deposition. Fluorescence properties and the FTIR data make it possible to detect this resinization and the presence of exudates enables the rank to be determined (Suárez-Ruiz et al., 1994b). The perhydrous character of Av is due to impregnation by petroleum-like substances that occurred in the early diagenetic stages and have migrated from other sediments. Such oils would only be retained inside ulminite, and would explain their fluorescence features, their reflectance suppression, the anomalies detected in rank parameters and the lower porosity found in the vitrain.

The results outlined above show that both Mesozoic coals have similar characteristics such as anomalous low reflectance, high hydrogen, volatile matter and carbon content and high oil yield and calorific value. The results obtained provide new data to support the perhydrous origin of the two samples reported previously (Suárez-Ruiz et al., 1994aSuárez-Ruiz et al., 1994b). It has been clearly demonstrated that the process of hydrogen-enrichment (resinization and impregnation) has modified the vitrinite network, thereby limiting the formation of polycyclic units and causing suppressed reflectance. Nevertheless, although 
some characteristics and properties are similar, the different nature of the hydrogenenrichment process for the two coals can be seen from the geochemical parameters, especially from the extract (yield and composition) study. Moreover, they show another difference: namely, $\mathrm{Tv}$ is quickly affected by air oxidation at room temperature while Av remains unaltered after long exposure in the same conditions. Thus, Av is a material known for its special properties and has been used for gem and ornamental purposes for many centuries.

Finally, the main factor that controls vitrinite chemistry in the perhydrous vitrains took place during their plant life (in the case of Tv) and post-sedimentary history (for Av). However, the different origin of the plant contribution and different environmental conditions at deposition play a significant role in the formation and evolution of the Thesozoic and Carboniferous vitrains.

\section{Acknowledgements}

We wish to thank Dr. Prado for his initial research proposals on the study of natural vitrinite. The authors are also indebted to J. Suarez Canga of the Chromatography and Chemical Analytical Services for analytical data and helping to set up the gas apparatus coupled to the Gray-King pyrolysis equipment. Financial support for this work was provided from Ministerio de Educacion y Cultura grant to A. Jiménez and through a contract from European Community (No. 7220-EC-757). I. Hutchinson has revised the English version. Comments from Dr. J. Newman and other anonymous referee are also very much appreciated.

\section{References}

Bertrand, Ph., 1989. Microfacies and petroleum properties of coals as revealed by a study of North Sea Jurassic coals. Int. J. Coal Geol. 13, pp. 575-595

Blanco, C.G., Prado, J.G., Guillen, M.D. and Borrego, A.G., 1992. Preliminary study of the extraction techniques in oil shales. Org. Geochem. 18, pp. 313-316

Brown, H.R., Cook, A.C. and Taylor, G.H., 1964. Variations in the properties of vitrinite in isometamorphic coal. Fuel 43, pp. 111-124

Campon, E., Fernandez, C.J., Solans Huguet, J., 1978. El Azabache de los Yacimientos de Oles (Asturias). Trabajos de Geologia, Univ. de Oviedo. 10, 161.

Carr, A.D. and Willianson, J.E., 1990. The relationship between aromaticity, vitrinite reflectance and maceral composition of coals: implication for the use of vitrinite reflectance as maturation parameter. Org. Geochem. 16 1-39, pp. 313-323

Cervera, A., Pardo, G. and Villena, J., 1976. Algunas precisiones litoestratigraficas sobre la formacion lignitos de Escucha. Tecniterre 14, pp. 25-33 
Crelling, J.C., Skorupska, N.M. and Marsh, H., 1988. Reactivity of coal macerals and lithotypes. Fuel 67, pp. 781-785

Curry, D.J., Bohacs, K.M., Diessel, C.F.K., Gammidge, L.C., Rigby, R., 1995. Sequence stratigraphic and depositional environment controls on the geochemistry and oil generation potential of coals and terrestrial kerogens. In: Grimalt, Dorronsoro (Ed.), Org. Geochem.: Developments and Applications to Energy, Climate, Environment and Human History. AIGOA, San Sebastian, pp. 138-140.

Durand, B., Nicaise, G., Vandenbroucke, M., Hagemann, H.W., 1977. Etude geochique d'une série de charbons. In: Campos, R., Goni, J. (Eds.), Advances in Organic Geochemistry. ENADIMSA, Madrid, pp. 601-632.

Durand-Souron, C., 1980. Thermogravimetric analysis and associated techniques applied to Kerogens. In: Durand, B. (Ed.), Kerogen Insoluble Organic Matter from Sedimentary Rocks, $143-161$.

Dyrkacz, G.R., Bloomquist, C.A.A. and Solomon, P.R., 1984. Fourier transform infrared study of high-purity maceral types. Fuel 63, pp. 536-542

Dyrkacz, G.R., Bloomquist, C.A.A. and Ruscic, L., 1991. An investigation of the vitrinite maceral group in microlithotypes using density gradient separation methods. Energy Fuel 5, pp. 155-163 Full Text via CrossRef | Abstract + References in Scopus | Cited By in Scopus

Espitalie, J., Laporte, J.L., Madec, M., Leplat, P. and Paulet, J., 1977. Methode rapide de caracterisation des roches méres, de leur potentiel pétrolier et de leur degré d'evolution. Rev. Inst. Fr. Pétr. 32, pp. 23-47

Espitalie, J., Deroo, G. and Marquis, F., 1985. La pyrolyse Rock-Eval et ses applications. Rev. Inst. Fr. Pétr. 40, pp. 563-783

Espitalie, J., Deroo, G. and Marquis, F., 1986. La pyrolyse Rock-Eval et ses applications. Rev. Inst. Fr. Pétr. 41, pp. 73-89

Espitalie, J., Bordenave M.L., 1993. Source Rock Parameters. In: Bordenave, M.L. (Ed.), Applied Petroleum Geochemistry, Chap. II, Vol. 2, Technip, Paris, pp. 237-272.

Fang, H. and Jianyu, C., 1992. The cause and mechanism of vitrinite reflectance anomalies. $J$. Petrol. Geol. 15, pp. 419-434

Fowler, M.G., Gentzis, T., Goodarzi, F. and Foscolos, A.E., 1991. The petroleum potential of some Tertiary lignites from northern Greece as determined using pyrolysis and organic petrological techniques. Org. Geochem. 17 6, pp. 805-826

Fujii, S. and Tsuboi, H., 1967. Helium densities and related properties of Japanese Coal. Fuel 46, pp. 361-366

Gan, H., Nandi, S. and Walker Jr., P., 1972. Nature of the porosity in American coals. Fuel 51, pp. 272-277 
Hatcher, P.G., 1989. Chemical structural models for coalified wood (vitrinite) in low rank coal. Adv. Org. Geochem. 16, pp. 959-968

Hatcher, P.G., Faulon, J.L., Wenzen, K.A. and Cody, G.D., 1992. A structural model for lignin-derived vitrinite from High volatiles Bituminous coal (Coalified wood). Energy and Fuels 6, pp. 813-820

Hatcher, P.G., Wenzen, K.A., Cody, G.D., 1994. Coalification reactions in vitrinite derived from coalified wood. In: Mukhopadhyay, P.K., Dow, W.G. (Eds.), Vitrinite Reflectance as a Maturity Parameter, Chap. 8, ACS Symposium Series 570, Washington, pp. 112-135.

Hodek, W., Kirschstein, J. and Heek, K., 1991. Reactions of oxygen containing structures in coal pyrolysis. Fuel 70, pp. 424-428

Hutton, A. and Cook, A., 1980. Influence of alginite in the reflectance of vitrinite from Joadja, N.S.W. and some other coals and oil shales containing alginite. Fuel 59, pp. 711-716

International Committee of Coal Petrology, 1975.International Handbook for Coal Petrology, 2nd edn., CNRS, Paris.

Iglesias, M.J., Jiménez, A., Laggoun-Defarge, F. and Suárez-Ruiz, I., 1995. FTIR study of pure vitrains and associated coals. Energy Fuels 9, pp. 458-466

International Standard ISO 349, 1975. Hard Coal. Audibert-Arnu Dilatomer Test.

International Standard ISO 1928, 1976. Solid Mineral Fuels. Determination of Gross Calorific Value by the Calorimetric Bomb Method and Calculation of Net Calorific Value. International Standard, 1st edn., 14 pp.

International Standard ISO 502, 1981. Coal. Determination of Coking Power. Gray-King Assay; International Standard, 2nd edn., 9 pp.

International Standard ISO 589, 1981. Hard Coal. Determination of Total Moisture. International Standard, 2nd edn., 6 pp.

International Standard ISO 562, 1981. Hard Coal and Coke. Determination of Volatile Matter Content. International Standard, 2nd edn., $5 \mathrm{pp}$.

International Standard ISO 1171, 1981. Solid Mineral Fuels. Determination of Ash. International Standard, 2nd edn., 2 pp.

International Standard ISO 7404/3, 1984. Methods for the Petrographic Analysis of Bituminous Coal and Anthracite-Part 3: Methods of determining group composition; International Standard, 1st edn., 4 pp.

International Standard ISO 7404/5, 1984. Methods for the Petrographic Analysis of Bituminous Coal and Anthracite-Part 3: Methods of determining microscopically the reflectance of vitrinite; International Standard, 1th edn., $13 \mathrm{pp}$. 
IUPAC, 1972. Manual of Symbols and Terminology. Appendix 2, Pt 1, Colloid and Surface Chemistry. Pure Appl. Chem. 31 (578)

Jiménez, A., 1995. Estudio del Grupo Vitrinitas en Carbones de Distinto Rango. Determinacion de sus Propiedades y Relaciones con su Génesis. PhD Thesis. Univ. Salamanca, p. 255, unpublished.

Jones, J.M., Davis, A., Cook, A.C., Murchison, D.G. and Scott, E., 1984. Provincialism and correlations between some properties of vitrinites. Int. J. Coal Geology 3, pp. 315-331

van Krevelen, D.W., 1993. Coal. Elsevier, pp. 979.

Kuehn, D.W., Snyder, R.W., Davis, A. and Painter, P.C., 1982. Characterization of vitrinite concentrates: 1. Fourier Transform infrared studies. Fuel 61, pp. 682-694

Laggoun-Defarge, F., Lallier Verges, E., Suárez-Ruiz, I., Jimenez, A., Guet, J.M., Clinard, Ch., 1994. Texture ultrafine des vitrinites. relations avec les propriétés optiques et physiques. Bull. Centres Rech. Explor.-Prod. Elf aquitaine 18, Publ. Spéc, 263-271.

Lin, R., Davis, A., Bensley, D.F. and Derbyshire, F., 1986. Vitrinite secondary fluorescence: its chemistry and relation to the development of a mobile phase and thermoplastic in coals. Int. J. Coal Geol. 6, pp. 215-228

Lin, R. and Davis, A., 1988. A fluorogeochemical model for coal macerals. Org. Geochem. 12, pp. 363-374

Lloyd, W.G., Reasoner, J.W., Hower, H.C. and Yates, L.P., 1990. Estimates of fluid properties of high volatile bituminous coals. Fuel 69, pp. 1257-1270

Mansuy, L., Landais, P. and Ruau, O., 1995. Importance of the Reacting Medium in Artificial Maturation of a Coal by Confined Pyrolysis: 1. Hydrocarbons and Polar compounds. Energy and Fuels 9, pp. 691-703

Marques, M., 1987. Informe Sobre los Carbones de Puertollano. Parte 1 y 2; Oporto. Rapport Interne.

Mastarlerz, M., 1991. Variation of vitrinite reflectance in a vertical seam section, an example from the Intrasudetic Basin, SW Poland. Soc. Geol. France 162 2, pp. 175-182

Mastarlerz, M. and Bustin, R.M., 1993. Electron microprobe and micro-FTIR analyses applied to maceral chemistry. Int. J. Coal Geol. 24, pp. 333-345

Mastarlerz, M. and Bustin, R.M., 1993. Variation in maceral chemistry within and between coals of varying rank: an electron microprobe and micro-Fourier transform infra-red investigation. J. of Microscopy 171, pp. 153-166

Mastarlerz, M. and Bustin, R.M., 1994. Variation in reflectance and chemistry of vitrinite and vitrinite precursors in a series of Tertiary Coals, Artic Canada. Org. Geochem. 6, pp. 921-933 
Mastarlerz, M. and Bustin, R.M., 1997. Variation in the chemistry of macerals in coals of the Mist Mountain Formation, Elk Valley coalfield, British Columbia, Canada. Int. J. Coal Geol. 33, pp. 43-59

Mazumdar, B.K., 1988. Aromaticity of coal: A reppraisal of the graphical-densimetric approach. Fuel Processing Technology 19, pp. 179-202

Mukhopadhyay, P.K., 1994. Vitrinite reflectance as Maturity parameter: petrographic and Molecular Characterization and its implication to Basin Modeling. In: Mukhopadhyay, P.K., Dow, W.G. (Eds.), Vitrinite Reflectance as a Maturity Parameter ACS Symp. Series, 1, pp. 124.

Neavel, R.C., Smith, S.E., Hippo, E.J. and Miller, R.N., 1986. Interrelationships between coal composition parameters. Fuel 65, pp. 312-320

Newman, J. and Newman, N.A., 1982. Reflectance anomalies in Pike River coals: evidence of variability in vitrinite type, with implications for maturation studies and 'Suggate rank'. N.Z. J. Geol. Geophys. 25, pp. 233-243

Newman, J., Price, L.C. and Johnston, J.H., 1997. Hydrocarbon source potential and maturation in Eocene New Zealand vitrinite rich coals. Insights from traditional coal analyses, and Rock-Eval and biomarker studies. J. Petrol. Geol. 20 2, pp. 137-163

Petrova, R., Mincev, D. and Nikolov, Z.D.R., 1985. Comparative investigations on gagate and vitrain from the Balkan coal basin. Int. J. Coal Geol. 5, pp. 275-280

Querol, X., Fernandez, J.L., Lopez, A., Hagemman, J.W., Dehmer, J., Juan, R. and Ruiz, C., 1991. Distribution of sulphur in coals of the Teruel Mining District, Spain. Int. J. Coal Geol. 18, pp. 327-346

Rochdi, A. and Landais, P., 1991. Transmission micro-infrared spectroscopy. Fuel 70, pp. $367-371$

Sandvik, E.I., Young, W.A. and Curry, D.J., 1991. Expulsion from hydrocarbon source: the role of organic absorption dv. Org. Geochem. 19, pp. 77-87

Schenk, H.J., Witte, E.G., Littke, R. and Schwochau, K., 1990. Structural modification of vitrinite and alginite concentrates during pyrolytic maturation at different heating rates. A combined infrared, 13C and microscopical study. Org. Geochem. 16, pp. 943-950

Smutkina, Z.S., Sekrieru, V.I., Titova, T.A. and Skripchrenko, G.B., 1982. A derivatographic investigation of hard coals as a raw material for destructive hydrogenation. Solid Fuel Chemistry 16, pp. 53-57

Stach, E., Mackowsky, M.Th., Teichmüller, M., Taylor, G.H., Chandra, D., Teichmüller, R., 1982. Textbook of Coal Petrology, 3rd edn., Borntraeger, Berlin, 535 p.

Stankiewicz, B.A., Kruge, M.A. and Mastarlerz, M., 1996. A geochemical study of macerals from a Miocene lignite and an Eocene bituminous coal, Indonesia. Org. Geochem. 24 5, pp. $531-545$ 
Suárez-Ruiz, I., Iglesias, M.J., Jimenez, A., Laggoun Defarge, F., Prado, J.G., 1994a, Petrographic and Geochemical anomalies detected in the Spanish Jet. In: Mukhopadhyay, P.K., Dow, W.G. (Eds.), Vitrinite Reflectance as a Maturity Parameter ACS Symp. Series, 6, 76-92.

Suárez-Ruiz, I., Jimenez, A., Iglesias, M.J., Laggoun Defarge, F. and Prado, J.G., 1994. Influence of the Resinite on huminite properties. Energy Fuels 8 6, pp. 1417-1424

Suárez-Ruiz, I., Prado, J.G., 1995. NATO Advances Study Institute: Composition, Geochemistry and Conversion of Oil Shales. Short Course, Abstract Booklet.

Suarez Vega, L., 1974. Estratigrafia del Jurasico de Asturias. Cuad. Geol. Iberica 3 I and II, p. 368

Teichmüller, M., 1971. Anwendung kohlenpetrogrphischer methoden bei der Erdoel un Erdgasprospektion Erdoel und Kohle, 24 (2) 69-76.

Teichmüller, M. and Durand, B., 1983. Fluorescence microscopical rank studies on liptinites and vitrinites in peat and coals, and comparison with the results of the Rock-Eval pyrolysis. Int. J. Coal Geol. 2, pp. 197-230

Teichmüller, M., 1987. Recent Advances in coalification studies and their applications to geology. In Coal and Coal bearing strata: recent advances. Geol. Soc. Spec. Publ. 32, pp. 127169

Teichmüller, M., 1989. The genesis of coal from the viewpoint of coal petrology. Int. J. Coal Geol. 12, pp. 1-87

Tissot, B.P., Welte, D.H., 1984. Petroleum Formation and Occurrence, 2nd edn. Springer, Heidelberg, 669 pp.

UNE-32005 Carbon. Determinación del Indice de Hinchamiento en Crisol, 6 pp.

Valenzuela, M., Garcia Ramos, J.C., Suarez de Centi, C., 1986. The Jurassic Sedimentation in Asturias (N Spain), Trabajos de Geologia. Univ. Oviedo. pp. 121-132

Vallé, B., 1984. Structuration du bassin de Blanzy (Saone et Loire); Dynamique du Remplissages Stéphaniens et place du charbon, tectoniques précoce et tardive. $\mathrm{PhD}$ Thesis, Univ. Dijon.

Veld, H., Leeuw, J.W., Sinnnghe Damsté, J.S., Fermont, W.J.J., 1994. Molecular characterisation of vitrinite maturation as revealed by flash pyrolysis methods. In: Mukhopadhyay, P.K., Dow, W.G. (Eds.), Vitrinite Reflectance as a Maturity Parameter, ACS Symp. Series, Chap. 10. ACS Symp. Series, pp. 149-160.

Verheyen, T.V., Jonhs, R.B. and Espitalie, J., 1984. An evaluation of Rock-Eval pyrolysis for the study of Australian coals including their kerogen and humic acid fractions. Geochim. Cosmochim. Acta. 48, pp. 63-70 
Wallis, R.J., 1983. A lacustrine/deltaic/fluvial/swamp succession from the Stephanian B of Puertollano, Spain. In: Sousa, M.J.L. (Ed.), Contributions to the Carboniferous Geology and Paleontology of the Iberian Peninsula, Univ. Porto, Fac. de Ciencias, pp. 51-63.

Wolfs, P.M.J., Krevelen, D.W. and Waterman, H.I., 1960. Chemical Structures and Properties of Coal: XXV. The carbonization of Coal models. Fuel 39, pp. 25-38

Wu, 1990. Sedimentologie et Diagenese des Charbons du Bassin de Blanzy-Montçeau: Approches Pétrographiques Et Géochimiques Organiques. PhD thesis, Orleans University, pp. 126. 


\section{Figures and Tables}

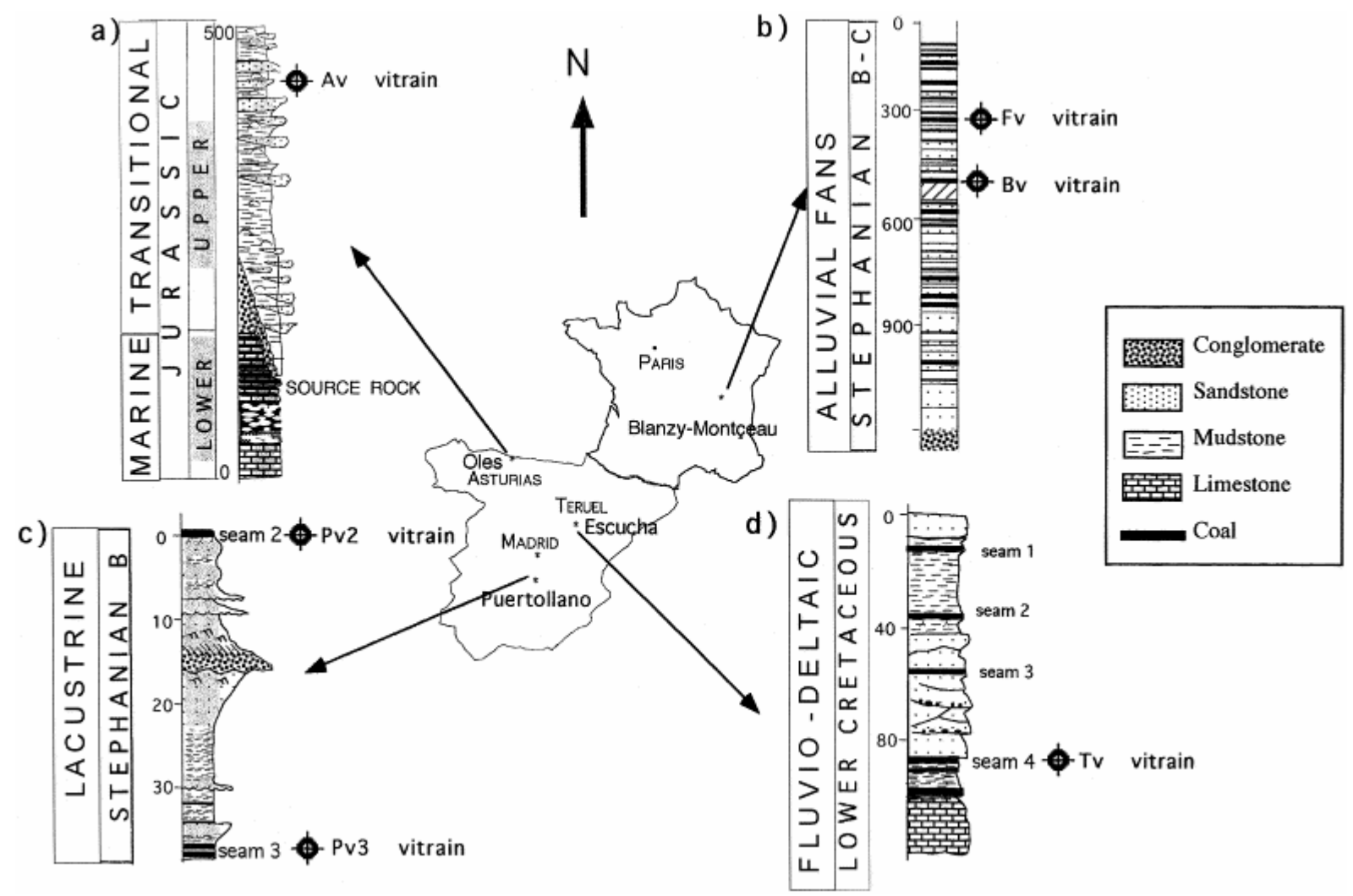

Fig. 1. Geographical and geological location of the vitrains in their corresponding stratigraphic series: (a) Jurassic sediments in the North of Spain (Valenzuela et al., 1986), (b) Blanzy-Montçeau Basin (Wu, 1990). (c) Puertollano Basin (Wallis, 1983), (d) UtrillasEscucha Basin (unpublished data, belonging to Conception mine).

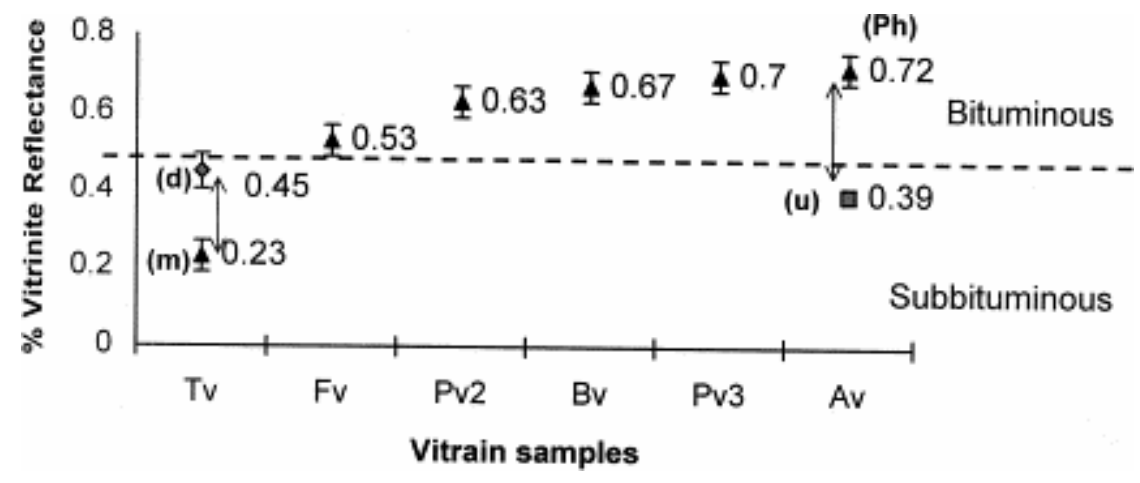

Fig. 2. Reflectance values of the vitrains located between the end of the diagenesis and the beginning of the catagenesis interval (bituminization stage). The bars in each sample show the standard deviation for the reflectance determinations. (m): measured, (d): deduced, $(\mathrm{u})$ : ulminite and $(\mathrm{Ph})$ : phlobaphinite. 


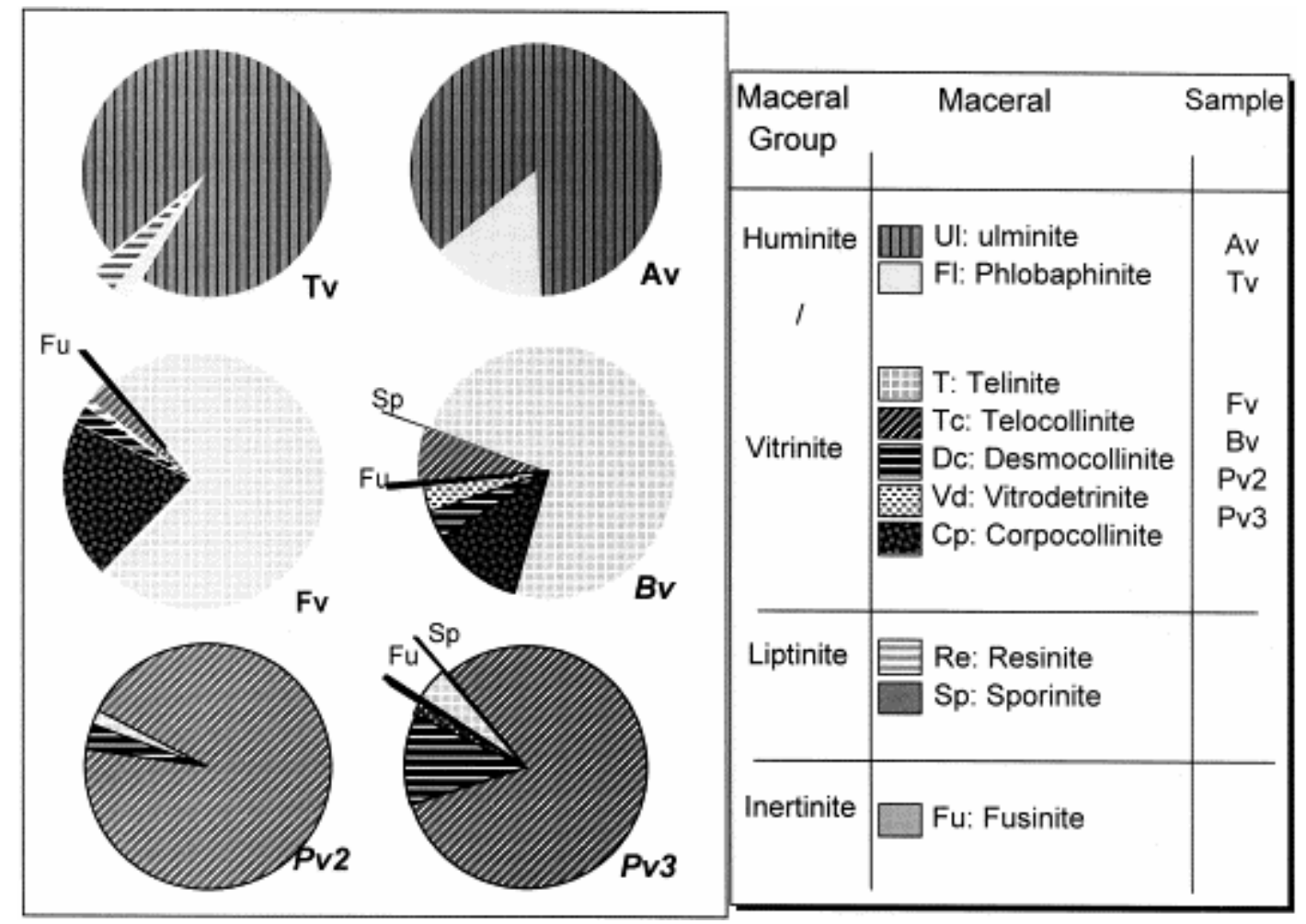

Fig. 3. Maceral analyses (\% vol. mmf) of the vitrains studied. In all cases the huminite/vitrinite group is predominant. Liptinite and inertinite maceral groups are minor.
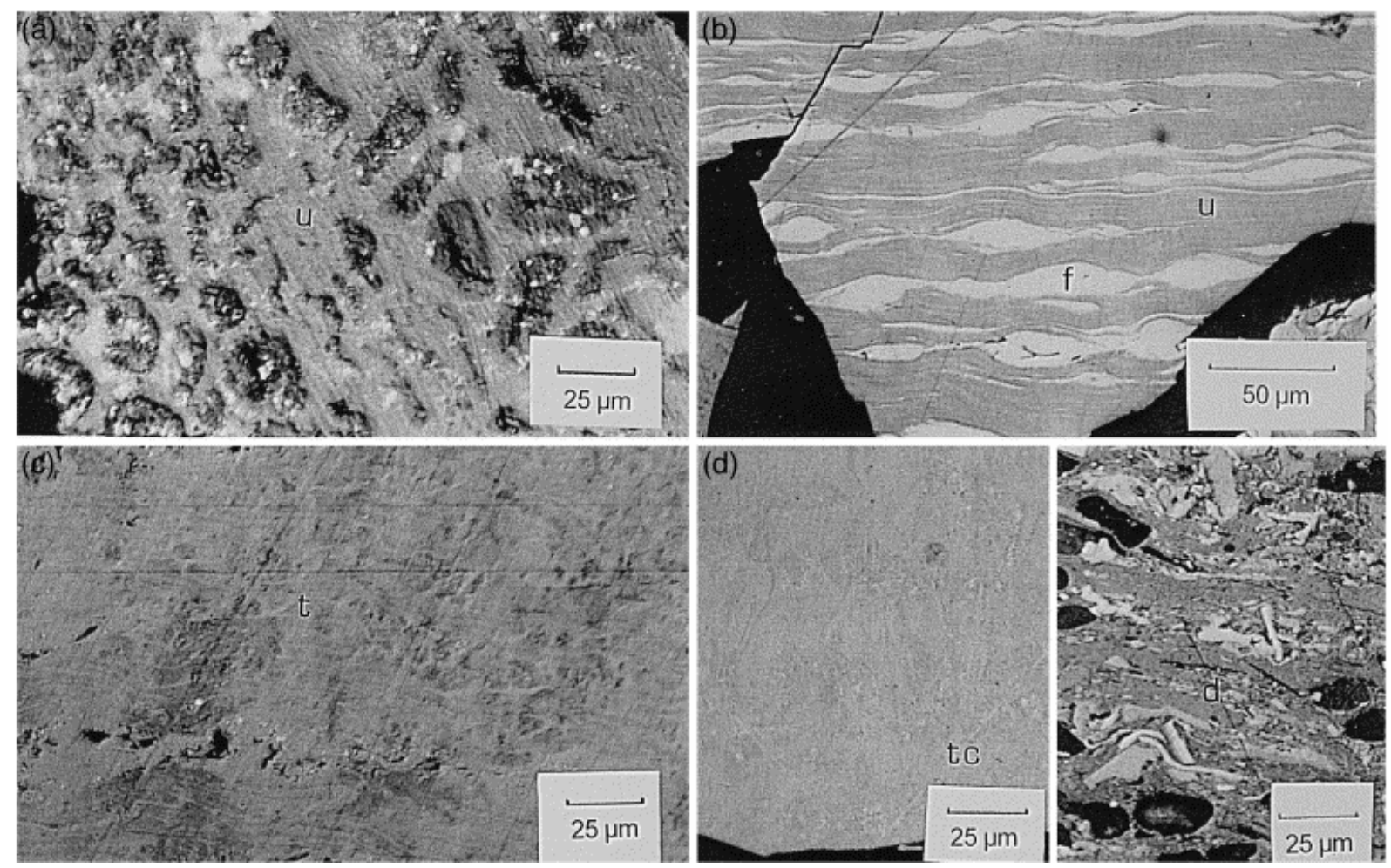

Fig. 4. Photomicrographs of the major organic components in the huminite/vitrinite maceral group identified in the vitrain samples using light and oil immersion. (a) Ulminite (u) with cell cavities filled with liptinitic substances in Tv. (b) Ulminite (u) and phlobaphiniten (f) showing cellular structures in Av. (c) Telinite (t) with cellular walls and cavities is the most 
common maceral in $\mathrm{Bv}$. In this vitrain, the gelification process is more marked than in the $\mathrm{Tv}$ and Av samples. (d) Telocollinite (tc) showing cellular structures remains indicating a high degree of gelification in Pv3. Desmocollinite (d) including liptinite and inertinite macerals.
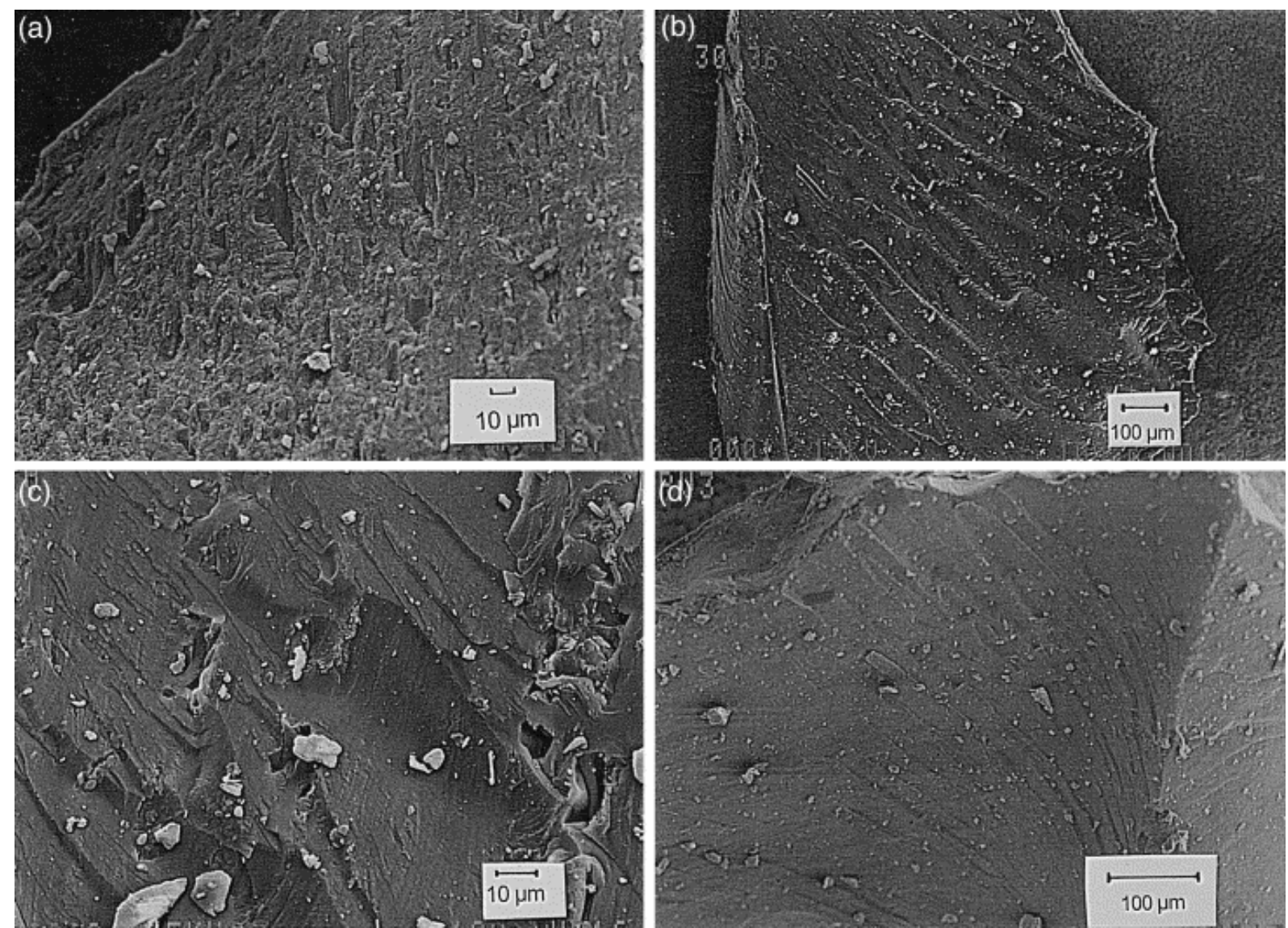

Fig. 5. SEM Photomicrographs showing the ultrastructure of the vitrains. (a) Woody structures with aligned cellular walls and cavities observed in Tv. (b) Amorphous matrix with a conchoidal fracture in Av. (c) Structures in $\mathrm{Bv}$ with cell walls, from a continuous sinuous layer. The latter delimits the cellular cavities which in some cases are filled with an amorphous matrix. d) Ultrafine structure of $\mathrm{Pv} 3$ with a conchoidal fracture and a compact amorphous matrix. 


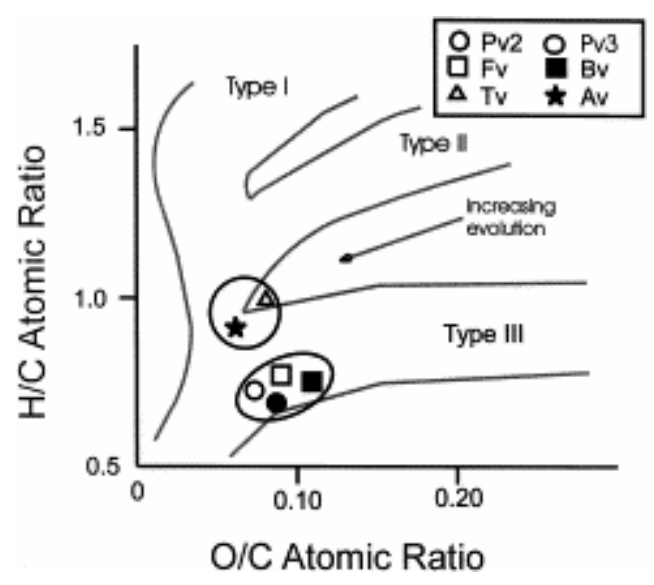

Fig. 6. Atomic $\mathrm{H} / \mathrm{C}$ vs. $\mathrm{O} / \mathrm{C}$ van Krevelen diagram showing two different areas occupied by the vitrains: Fv, Bv, Pv2 and Pv3 are inside the type III Kerogen band while Tv and Av are next to type II Kerogen.

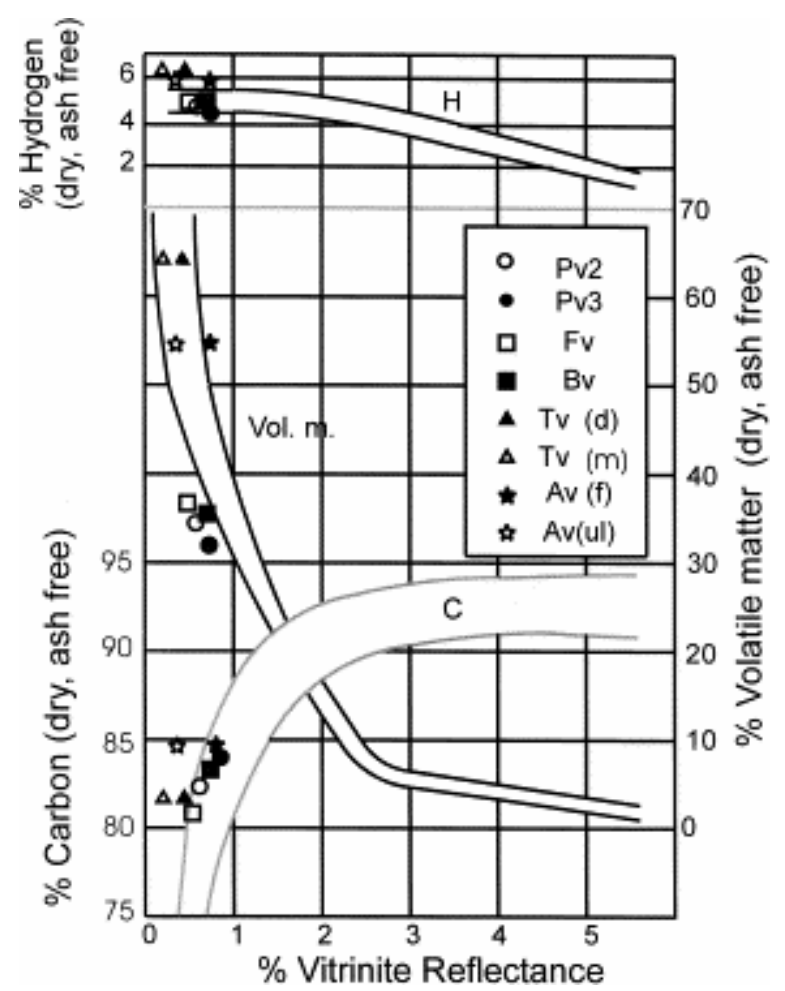

Fig. 7. Position of the vitrains in correlation bands between chemical ( $\% \mathrm{C}, \% \mathrm{H}$ and $\%$ V.M.) and petrographic parameters $\left(\% R_{\mathrm{o}}\right)$ established by Teichmüller (1971). Av(f) corresponding to phlobaphinite and $\operatorname{Av}(\mathrm{ul})$ to ulminite reflectance values. $\operatorname{Tv}(\mathrm{m})$ measured and $\operatorname{Tv}(\mathrm{d})$ deduced reflectance values. 

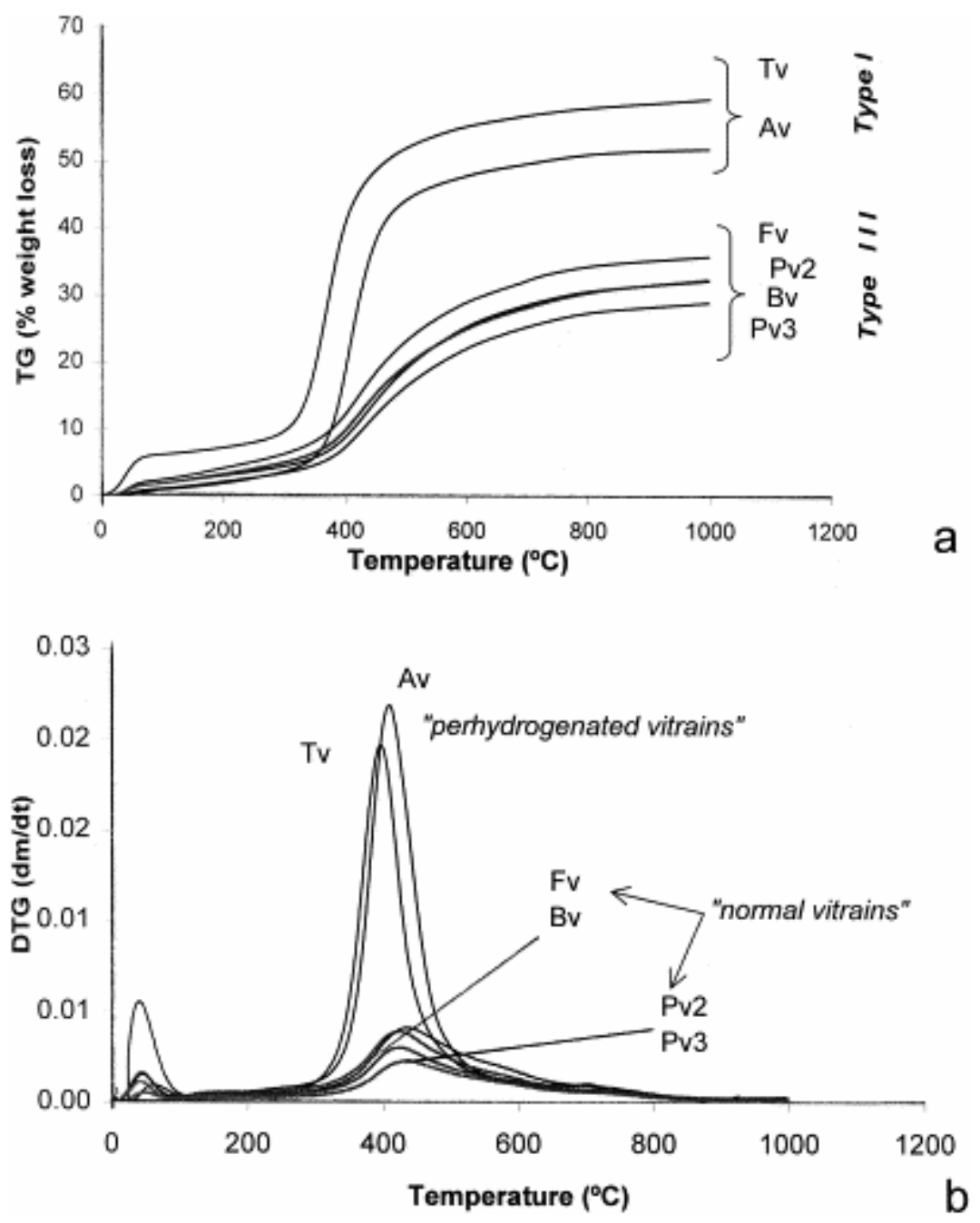

Fig. 8. Thermal behaviour of the vitrains during thermogravimetric analysis. (a) TG curves (\% weight loss) showing the different behaviour of the vitrains during pyrolysis. (b) DTG curves obtained for the vitrains during pyrolysis.

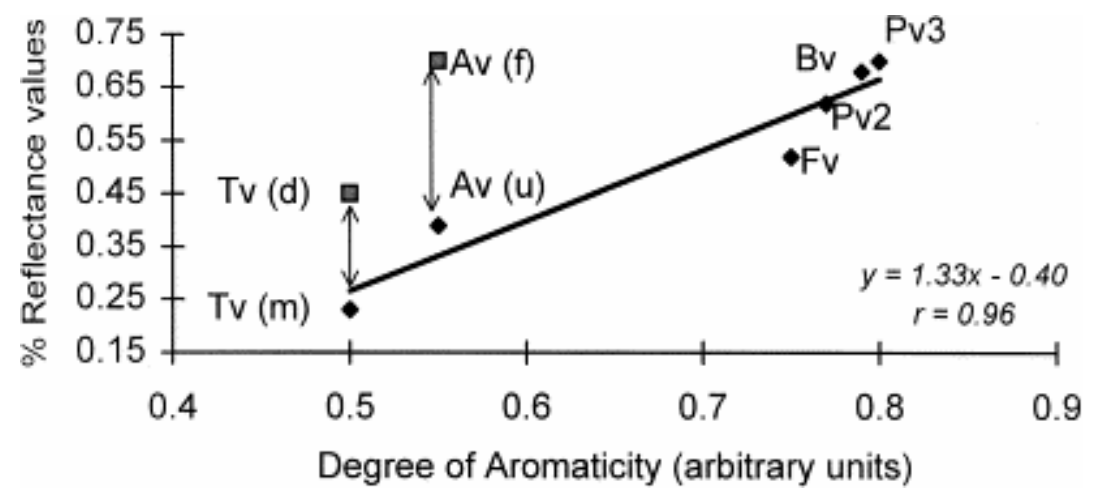

Fig. 9. Increasing degree of aromaticity with reflectance values obtained for the vitrains. In TV the measured- $\mathrm{Tv}(\mathrm{m})$ - and deduced - $\mathrm{Tv}(\mathrm{d})$ - reflectance values have been considered. Phlobaphinite-Av(f) - and ulminite-Av(u) - values have been drawn for the Av sample. 

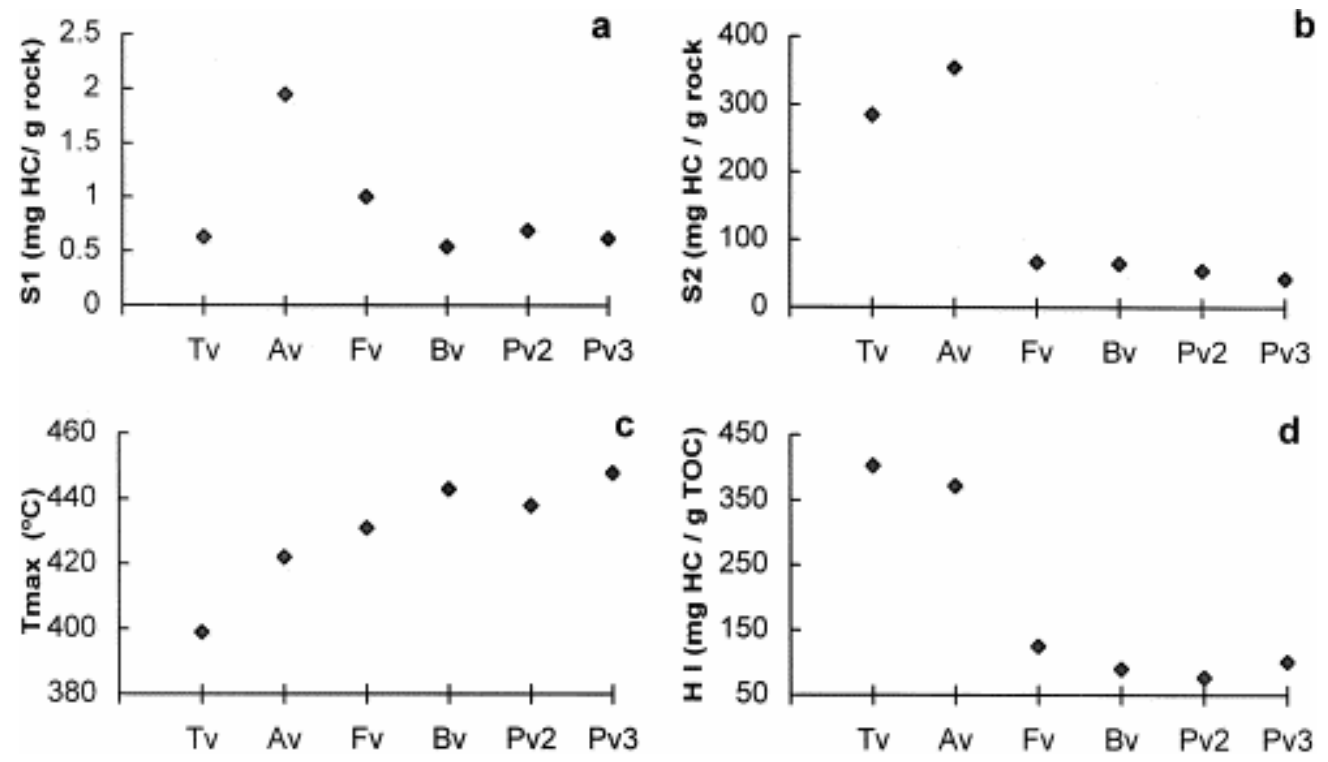

Fig. 10. Variation of the $S_{1}, S_{2}, T_{\max }$ and HI values from Rock-Eval pyrolysis for the vitrains studied here.

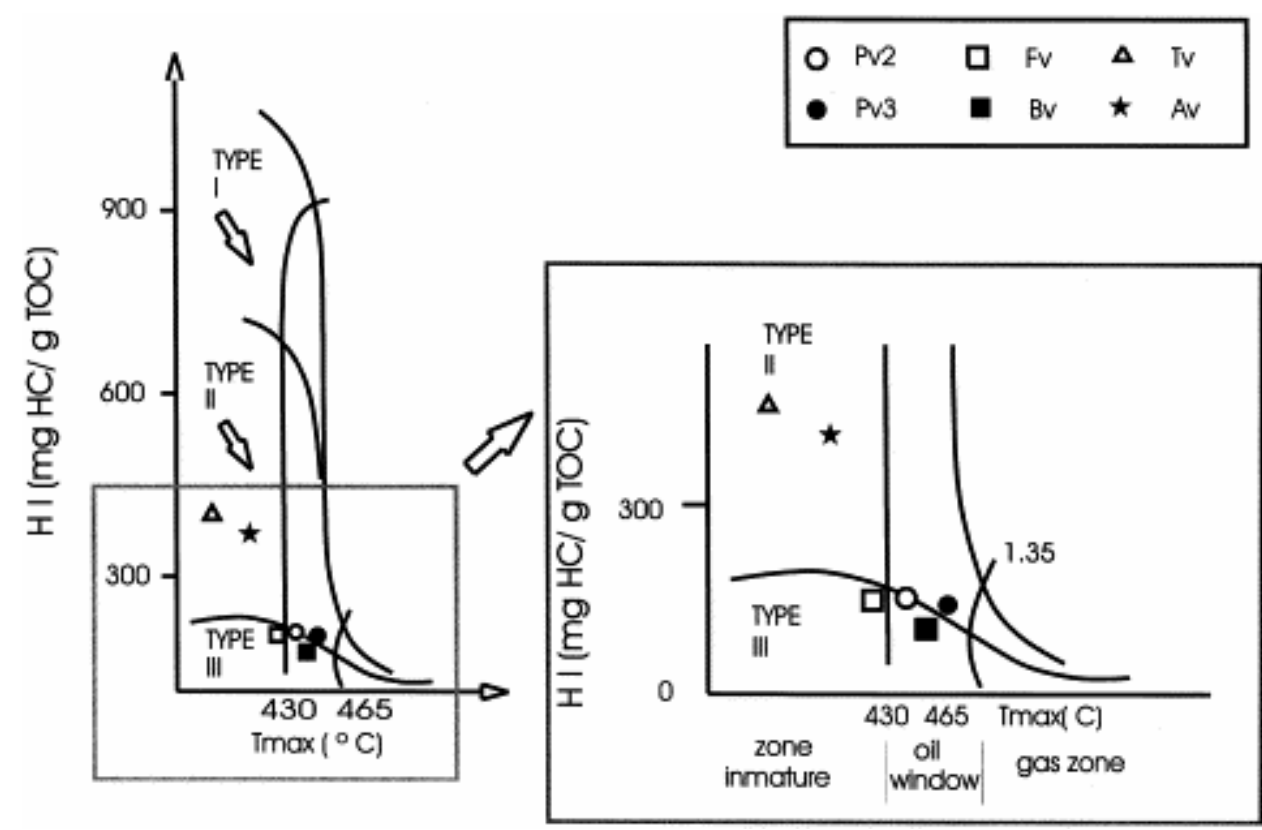

Fig. 11. $T_{\max }$ vs. HI diagram (Espitalie et al., 1985) showing the position of Fv, Bv, Pv2 and Pv3 vitrains inside Type III Kerogen while Tv and Av are located next to Type II Kerogen. 


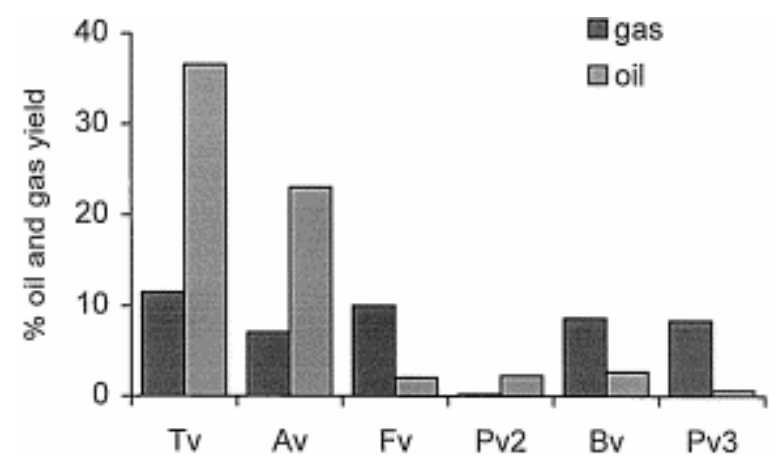

Fig .12. Gas and oil yield obtained from the Gray-King pyrolysis (at $550^{\circ} \mathrm{C}$ ) of the vitrain samples.

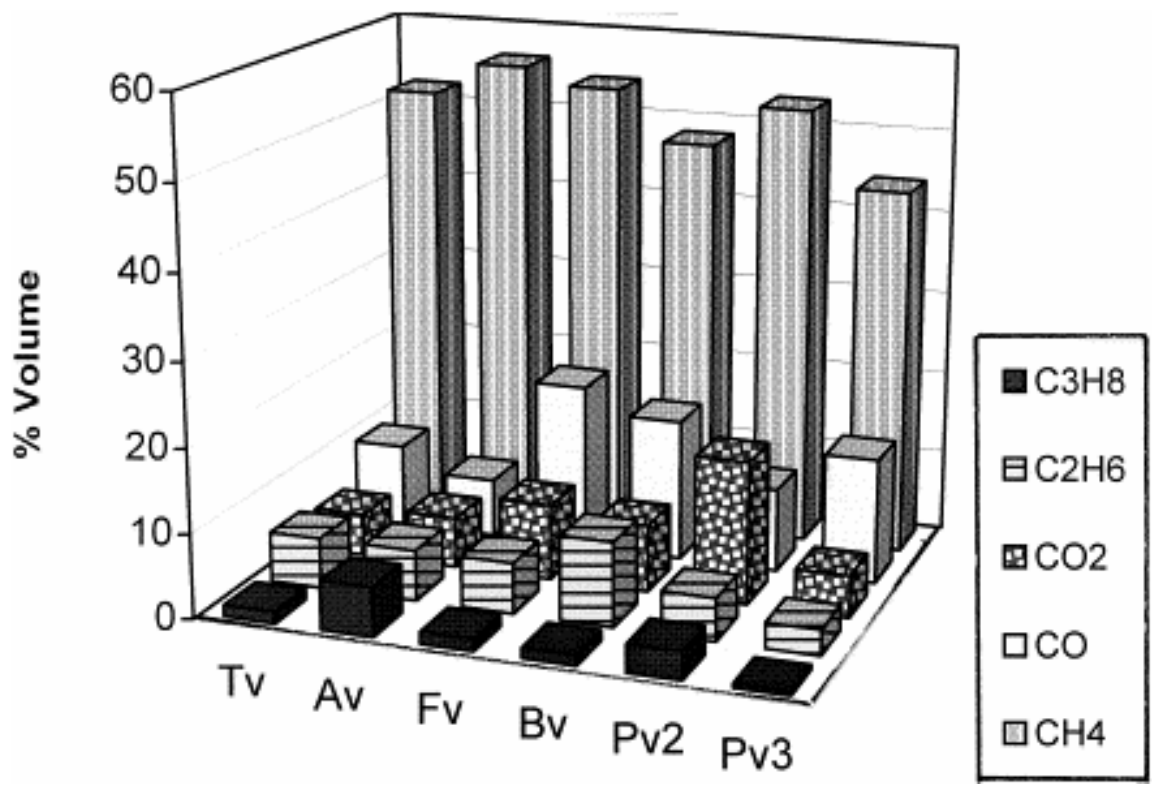

Fig. 13. Composition of the more abundant gaseous compounds obtained from the Gray-King pyrolysis (at $\left.550^{\circ} \mathrm{C}\right)$.

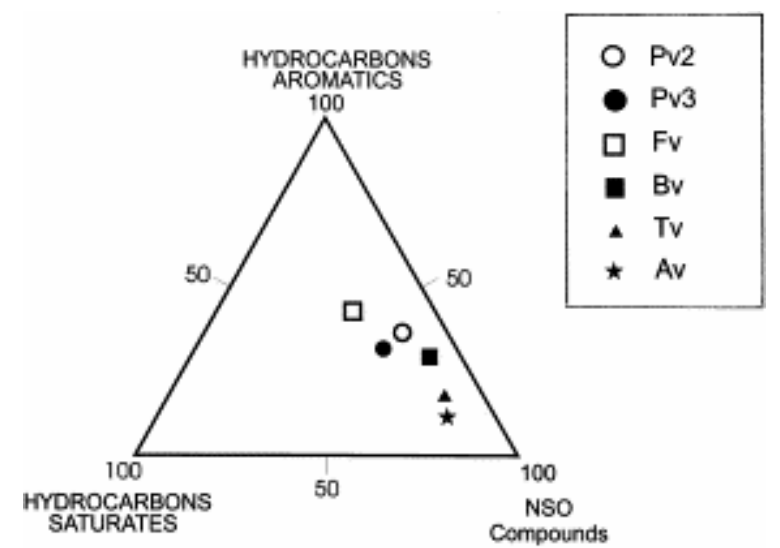

Fig. 14. Organic composition of the extract obtained from chloroform treatment. 


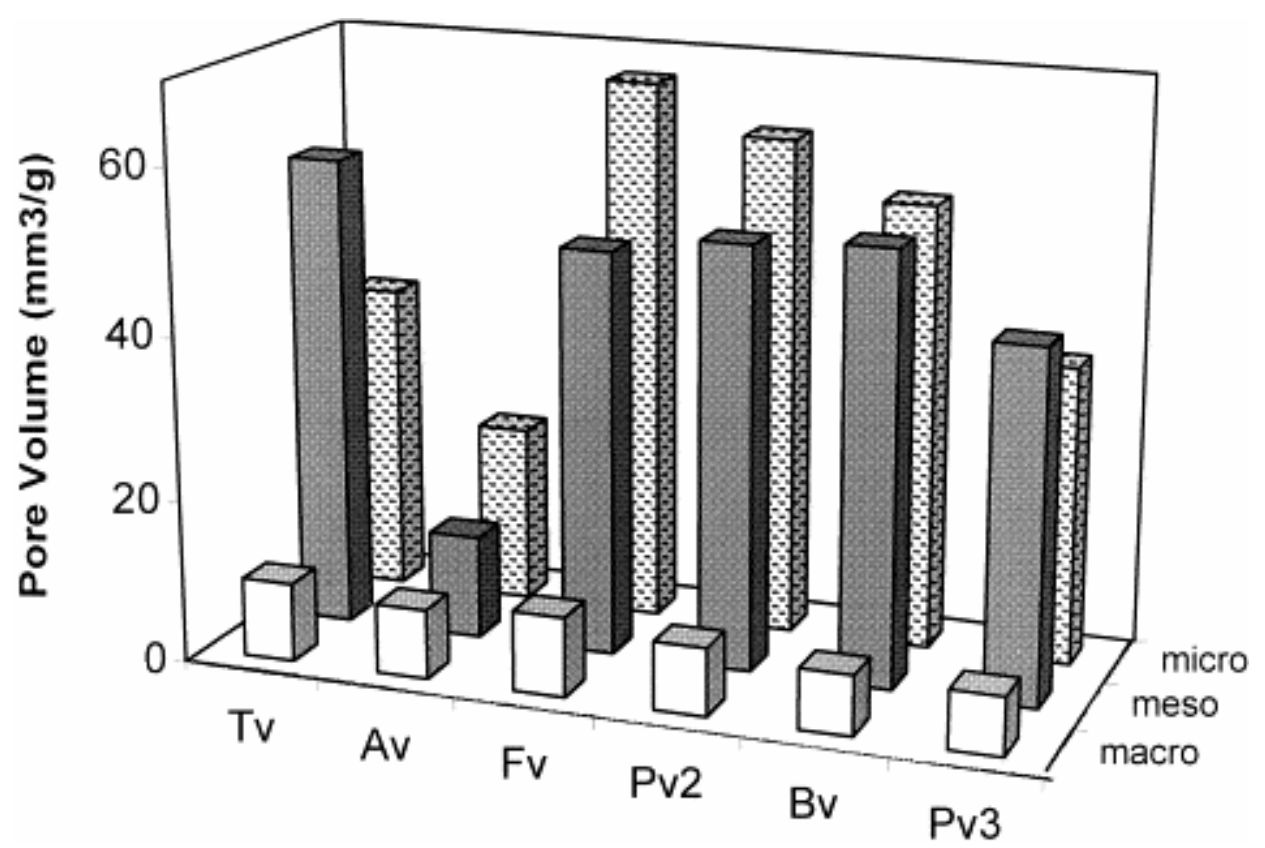

Fig. 15. Distribution of the pore volume for the different vitrains. $P_{\mathrm{d}}=$ pore diameter size (following IUPAC, 1972). 

Table 1. Chemical analyses and calorific values of the vitrain samples

\begin{tabular}{|c|c|c|c|c|c|c|c|c|c|}
\hline \multirow[t]{2}{*}{ Sample } & \multicolumn{3}{|c|}{ Proximate analyses } & \multicolumn{5}{|c|}{ Ultimate analyses } & \multirow{2}{*}{ 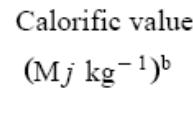 } \\
\hline & $\begin{array}{l}\text { Bed Moisture } \\
(\%)\end{array}$ & $\begin{array}{l}\text { Ash } \\
(\%)^{\mathrm{a}}\end{array}$ & $\begin{array}{l}\text { Volatile } \\
\text { matter }(\%)^{b}\end{array}$ & $\mathrm{C}(\%)^{\mathrm{b}}$ & $\mathrm{H}(\%)^{\mathrm{b}}$ & $\mathrm{O}(\%)^{\mathrm{b}}$ & $\mathrm{N}(\%)^{\mathrm{b}}$ & $\mathrm{S}(\%)^{\mathrm{a}}$ & \\
\hline $\mathrm{Tv}$ & 14.0 & 3.8 & 64.2 & 81.7 & 6.2 & 9.5 & 0.5 & 2.9 & 33.4 \\
\hline $\mathrm{Fv}$ & 11.0 & 1.5 & 36.8 & 81.5 & 4.8 & 12.0 & 1.2 & 0.5 & 33.2 \\
\hline Pv2 & 12.1 & 2.7 & 34.2 & 82.6 & 4.8 & 10.0 & 1.7 & 1.2 & 32.6 \\
\hline $\mathrm{Bv}$ & 10.2 & 0.8 & 34.4 & 83.5 & 4.9 & 9.8 & 1.1 & 0.8 & 31.7 \\
\hline Pv3 & 8.3 & 3.2 & 31.5 & 83.1 & 4.7 & 9.7 & 1.9 & 0.7 & 32.3 \\
\hline $\mathrm{Av}$ & 2.3 & 1.1 & 54.9 & 84.8 & 5.9 & 7.4 & 0.9 & 1.0 & 35.2 \\
\hline
\end{tabular}

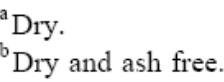

Table 2. Thermogravimetric results and extraction yield

\begin{tabular}{lllll}
\hline Sample & $\begin{array}{l}\text { Weight loss } \\
(\%)\end{array}$ & $\mathrm{DTG}_{\max }{ }^{\circ} \mathrm{C}$ & $\mathrm{A}$ & $\begin{array}{l}\text { Extract yield } \\
\left(\mathrm{mg} \mathrm{g}^{-1} \mathrm{OC}\right)\end{array}$ \\
\hline $\mathrm{Tv}$ & 60 & 386 & 0.50 & 17.1 \\
$\mathrm{Av}$ & 52 & 432 & 0.55 & 2.5 \\
$\mathrm{Fv}$ & 37 & 432 & 0.75 & 3.7 \\
Pv2 & 33 & 433 & 0.77 & 3.4 \\
Bv & 32 & 435 & 0.79 & 3.1 \\
Pv3 & 31 & 440 & 0.80 & 2.8 \\
\hline
\end{tabular}


Table 3. Textural data (dry basis) of vitrains

\begin{tabular}{lllllll}
\hline Sample & $\begin{array}{l}\text { True density } \\
\left(\mathrm{g} \mathrm{cm}^{-3}\right)\end{array}$ & $\begin{array}{l}\text { True density } \\
(\text { calculated) }\end{array}$ & $\begin{array}{l}\text { Standard } \\
\text { deviation }\end{array}$ & $\begin{array}{l}\text { Apparent density } \\
\left(\mathrm{g} \mathrm{cm}^{-3}\right)\end{array}$ & $\begin{array}{l}\text { Pore volume } \\
\left(\mathrm{mm}^{3} \mathrm{~g}^{-1}\right)\end{array}$ & $\begin{array}{l}\text { Porosity } \\
(\%)\end{array}$ \\
\hline Tv & 1.27 & 1.19 & -4.95 & 1.12 & 106 & 11.8 \\
Fv & 1.37 & 1.36 & -0.71 & 1.17 & 125 & 14.6 \\
Pv2 & 1.38 & 1.34 & -2.12 & 1.18 & 123 & 14.5 \\
Bv & 1.34 & 1.34 & 0 & 1.16 & 116 & 13.4 \\
Pv3 & 1.34 & 1.36 & +1.41 & 1.20 & 87 & 4.4 \\
Av & 1.23 & 1.24 & +0.71 & 1.17 & 42 & 4.9 \\
\hline
\end{tabular}

Table 4. Audibert-Arnu swelling and Free Swelling data.

\begin{tabular}{llll}
\hline Sample & \multicolumn{2}{l}{ Audibert-Arnu Swelling } & Free Swelling \\
\cline { 2 - 3 } & $\mathrm{a}$ & $\mathrm{b}$ & Index \\
\hline Tv & & 1 \\
Fv & -7 & -7 & $1 / 2$ \\
Pv2 & -5 & -5 & $1 / 2$ \\
Bv & -7 & -7 & 1 \\
Pv3 & -4 & -4 & 0 \\
Av & & & $51 / 4$ \\
\hline
\end{tabular}

a: contraction.

b: expansion. 